\title{
SOVEREIGN DISOBEDIENCE: THE ROLE OF U.S. COURTS IN CURTAILING THE PROLIFERATION OF SOVEREIGN DEFAULT
}

\author{
Joshua Burress
}

\section{INTRODUCTION}

\section{A. The Argentine Financial Crisis}

On December 23, 2001, Argentine President Adolfo Rodríguez Sáa declared that Argentina intended to default on more than $\$ 95$ billion in external debt. ${ }^{1}$ Prior to being unseated by Greece in March of 2012, ${ }^{2}$ Argentina's declaration of default was the largest in history. ${ }^{3}$ However, the significance of Argentina's default would not be eclipsed quite so easily. Thanks to the Second Circuit Court of Appeals and its recent decision in NML Capital, Ltd. v. Republic of Argentina, ${ }^{4}$ not only has the notoriety of Argentina's default been revitalized, it may soon be acclaimed for predicating substantial developments in the Supreme Court's sovereign default jurisprudence. ${ }^{5}$

In $N M L$, the Second Circuit upheld a high-profile injunction imposed by the district court against the country of Argentina. ${ }^{6}$ The underlying lawsuit was precipitated by Argentina's default on municipal bonds held by private investors. ${ }^{7}$ After placing a moratorium on the payment of these bonds, Argentina made the decision to restructure its debt, culminating in a "take it or leave it" offer of new bonds ("Exchange Bonds") to then-current bondholders. ${ }^{8}$ The plaintiffs in $N M L$ represent a group of "holdout" creditors

\footnotetext{
${ }^{1}$ Romain Zamour, Note, Nml v. Argentina and the Ratable Payment Interpretation of the Pari Passu Clause, 38 Yale J. INT'L L. 55 (2013).

${ }^{2}$ Greece's Default: The Wait is Over, THE ECONOMIST (March 17, 2012), http://www.economist .com/node/21550271.

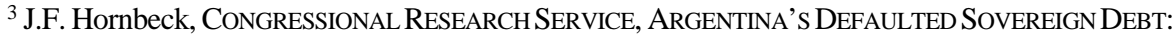
DEALING WITH THE “HOLDOUTS” 1 (Feb. 6, 2013), https://www.fas.org/sgp/crs/row/ R41029.pdf.

${ }^{4}$ NML Capital, Ltd. v. Republic of Argentina, 2013 WL 4487563 (2d Cir. Aug. 23, 2013) [hereinafter NML].

${ }^{5}$ See Petition for Writ of Certiorari, The Republic of Argentina v. NML Capital, Ltd., No. 13-990, 2014 WL 662133 (U.S. Feb. 18, 2014); see also Petition for Writ of Certiorari, Exchange Bondholder Group v. NML Capital, Ltd., No. 13-991, 2014 WL 890889 (U.S. Feb. 18, 2014).

${ }^{6}$ NML Capital, 727 F.3d at 248.

${ }^{7}$ Id. at 251.

${ }^{8} I d$. at $252-53$.
} 
whom declined Argentina's "exchange offer." ${ }^{9}$ Under the terms of the offer, Argentina would exchange the defaulted bonds for "unsecured and unsubordinated external debt at a rate of between twenty-five to twenty-nine cents on the dollar." ${ }^{10}$ Not only did Argentina cease all payments to creditors who did not accept the exchange, the government also enacted legislation making the previous moratorium permanent and declaring the holdouts would never be paid. ${ }^{11}$

After lengthy litigation, and in light of Argentina's explicit statements to both the public and the court that it would not comply with any order to pay the holdouts, the district court issued injunctions enjoining Argentina from paying any of its Exchange bondholders without simultaneously paying its previous bondholders. ${ }^{12}$ The court's decision was based on its interpretation of a pari passu clause in the parties' contract, ${ }^{13}$ which the court held required Argentina to make "ratable payments" to the holdout creditors. ${ }^{14}$ This meant that Argentina would have to pay the holdout creditors the same percentage of whatever amount it paid to holders of the Exchange Bonds when the next payment came due. ${ }^{15}$ Because the court found Argentina to be in default, and the remedy for default under the terms of the parties' contract was acceleration, this ruling essentially meant that upon making 100 percent of the next payment due to the Exchange holders, Argentina would be required to pay the holdout creditors 100 percent of the accelerated principal, plus interest. ${ }^{16}$

\section{B. Issues}

This Note argues that the injunction crafted by the district court and affirmed by the Second Circuit Court of Appeals should be abrogated by a Congressional amendment to the Foreign Sovereign Immunities Act ("FSIA"). ${ }^{17}$ The Second Circuit correctly found that Argentina had unequivocally breached the terms of the pari passu clause contained in the bonds when it ceased all payments to holders of earlier bonds in favor of those whom accepted new Exchange Bonds. However, the significance of the Second Circuit's decision is not the result reached, but rather its affirmation

\footnotetext{
${ }^{9}$ NML Capital, Ltd. v. Republic of Argentina, 727 F.3d 230, 251-252 (2d Cir. 2013).

${ }^{10} \mathrm{Id}$. at 252.

${ }^{11} \mathrm{Id}$.

12 Id. at 237-38 \& n.4.

${ }^{13}$ NML Capital, Ltd. v. Republic of Argentina, 699 F.3d 246, 251 (2d Cir. 2013)..

${ }^{14} \mathrm{Id}$.

${ }^{15} \mathrm{Id}$. at 238-39 (e.g. if Exchange holders receive 100 percent of what is owed to them on the next installment, the holdouts would also receive 100 percent of what is owed to them at that time.)

${ }^{16}$ Id. at 239.

17 On June 16, 2014, the Supreme Court of the United States denied Argentina's petition for writ of certiorari in NML Capital, Ltd. v. Republic of Argentina, 727 F.3d 230 (2d Cir. 2013). Republic of Argentina v. NML Capital, Ltd., 134 U.S. 2819 (2014).
} 
of the remedy crafted by the district court. Without a doubt, the most controversial aspect of the Second Circuit's opinion was its holding that the district court's injunctions did not run afoul of the Foreign Sovereign Immunities Act. The Second Circuit took no issue with the district court's injunctions, finding instead that the district court was well within its discretion in ordering that notice be disseminated to Argentina's third-party payment system participants. Pursuant to Rule 65(d) of the Federal Rules of Civil Procedure ("Rule 65"), this meant that these third parties could be held liable for assisting Argentina in violating the district court's injunctions, which the Second Circuit held was not the functional equivalent of an attachment or arrest of Argentina's assets.

This Note proceeds in three parts. The first part provides a factual background for understanding the sovereign debt market, as well as the significance of a sovereign's default on its obligations to private creditors. The first part also explains the proliferation of "holdout" litigation and the rise of "vulture" creditors. It concludes by providing background information regarding the FSIA and its application in sovereign debt litigation. The second part juxtaposes the NML injunctions with decisions from other Circuits, as well as the provisions of the FSIA. It concludes by arguing that the Second Circuit erred in holding that the NML injunctions did not violate the FSIA. The third part argues that Congress should abrogate the Second Circuit's opinion by amending the FSIA to prohibit the imposition of permanent injunctions against foreign states.

\section{BACKGROUND AND HISTORY}

\section{A. The Sovereign Debt Market}

As one commentator put it, "[g]overnment bonds are at the heart of public finance and play a central role in the development of capital markets." 18 A foreign state's participation in the sovereign debt market is closely analogous to that of a private borrower. ${ }^{19}$ The foreign state will issue municipal bonds, ${ }^{20}$ with the terms typically including a waiver of immunity from jurisdiction in any country in which the obligations of the bonds are sought to be enforced. ${ }^{21}$ If the foreign state is no longer able to service its external debt, it will typically attempt to restructure the debt. The term "debt restructuring” generally refers to changing the original terms/obligations of

\footnotetext{
${ }^{18}$ Michael Waibel, Opening Pandora's Box: Sovereign Bonds in International Arbitration, 101 AM. J. INT'L L. 711, 711 (2007) (alteration in original).

${ }^{19} \mathrm{Id}$. at 712 .

${ }^{20}$ Municipal Bond, INVESTOPEDIA, http://www.investopedia.com/terms/m/municipalbond .asp (last visited March 13, 2014) (defining “municipal bond” as, “[a] debt security issued by a state...to finance its capital expenditures”) (alteration in original).

${ }^{21}$ Waibel, supra note 18 , at 712.
} 
the debt instrument. ${ }^{22}$ The most common restructuring mechanism invoked by foreign states is a bond exchange. ${ }^{23}$

A bond exchange is essentially a place where a foreign state extends an offer to its current bondholders to exchange old bonds-on which the foreign state has defaulted-for new bonds with rescheduled payments and/or terms. ${ }^{24}$ Bondholders are often forced to accept these bond exchanges due to the sheer amount of leverage held by sovereign debtors, which is evident from the fact that there is currently no mechanism by which a foreign state may be compelled to transfer assets in its possession for the satisfaction of the claims of its creditors. ${ }^{25}$ As one commentator points out, "legal remedies for the protection of sovereign creditors are generally ineffective, largely because sovereign debt litigation in national courts runs into the constraint of sovereign immunity from enforcement, coupled with a limited pool of attachable assets abroad." 26

Notwithstanding the seemingly uphill battle creditors face in choosing to litigate rather than acceding to a sovereign's proposed restructuring, "holdout litigation" has steadily increased in recent years. ${ }^{27}$ Holdout litigation refers to a situation in which a sovereign has attempted to restructure its debt, either following or in anticipation of a default, and a minority of its creditors refuse to accept the offer-instead opting to hold out-in hopes of receiving the full face value of their debt. ${ }^{28}$ These holdout creditors have often been criticized as being pure opportunists with no regard for the potential ramifications of hindering sovereign debt restructurings or for the interests of their fellow creditors. ${ }^{29}$ The most common type of holdout creditor is what is known as a "vulture fund." The term "vulture fund" generally refers to an investment fund - such as a hedge fund or mutual fund-, which purchases sovereign debt on the secondary market at deeply discounted rates and then sues the sovereign debtor for the full face value of the debt pursuant to its original terms. ${ }^{30}$

22 Federico Sturzenegger \& Jeromin Zettelmeyer, Debt Defaults and Lessons from a DECADE OF CRISES 3 (2006).

23 See generally Lex Rieffel, Restructuring Sovereign DeBt: The CASE FOR Ad HoC MACHINERY (2003) (illustrating the predominance of bond exchanges in recent decades).

${ }^{24}$ Id.

${ }^{25} \mathrm{Id}$. at 13.

${ }^{26}$ Waibel, supra note 18 , at 713.

27 See generally, Julian Schumacher et al., Sovereign Defaults in Court: The Rise of Creditor Litigation 1976-2010 (April 15, 2013), available at http://ssrn.com/abstract=2189997 (illustrating a drastic rise in litigation since the mid 1990's).

${ }^{28}$ Jill E. Fisch \& Caroline M. Gentile, Vultures or Vanguards?: The Role of Litigation in Sovereign Debt Restructuring, 53 EMORY L.J. 1043, 1045 (2004).

${ }^{29} I d$.

${ }^{30}$ See Jonathan C. Lippert, Note, Vulture Funds: The Reason Why Congolese Debt May Force a Revision of The Foreign Sovereign Immunities Act, 21 N.Y. INT'L L. REv. 1, 2 n.7 (2008). 


\section{B. The Rise of Creditor Litigation}

A recent study of sovereign debt default indicates that a total of $108^{31}$ lawsuits were filed in the U.S. and U.K. from 1976 to $2010 .^{32}$ However, what is interesting about that number is that "more than half of these cases have been filed since the year 2000." 33 Moreover, "[t]he likelihood that a debt crisis is accompanied by creditor litigation has more than doubled over the past decade, to more than $40 \%$ in recent years." ${ }^{34}$ Remarkably, this rise in sovereign debt litigation has been seemingly unaffected by increasing litigation costs ${ }^{35}$ or the increase in the average duration of litigation in these types of cases, which is approximately six years. ${ }^{36}$ The explanation for this phenomenon begins to materialize upon closer inspection of the creditors behind the lawsuits. In the mid-1990s, a common denominator developed between the plaintiffs bringing these lawsuits: the majority of the plaintiffs were vulture funds. ${ }^{37}$ Indeed, from 2000-2010, almost 90 percent of all lawsuits involving sovereign default were brought by vulture funds. ${ }^{38}$ However, this data only partially explains the drastic increase in sovereign debt litigation, ${ }^{39}$ leaving unanswered the question as to why sovereign debt speculation suddenly became so attractive to vulture funds. The answer can be derived by considering four significant developments that occurred between 1985 and $2000 .{ }^{40}$

The first of these developments was brought about by the Second Circuit's opinion in Allied Bank Int'l v. Banco Credito Agricola de Cartago. ${ }^{41}$ In Allied, three banks - wholly owned by Costa Rica - defaulted on a loan they had received from a syndicate of commercial banks. ${ }^{42}$ Allied Bank International (“Allied Bank”), as designated agent of the syndicate, brought suit in federal court against the three Costa Rican banks and subsequently

31 This figure does not include additional lawsuits brought by the same creditor on the same debt. Schumacher et al., supra note 27, at 2.

${ }^{32}$ Id.

${ }^{33} \mathrm{Id}$.

${ }^{34}$ Id.

${ }^{35}$ Schumacher, supra note 27, at 3.

${ }^{36}$ Id.

${ }^{37} \mathrm{Id}$.

${ }^{38} \mathrm{Id}$.

${ }^{39}$ See Christopher C. Wheeler \& Amir Attaran, Declawing the Vulture Funds: Rehabilitation of a Comity Defense in Sovereign Debt Litigation, 39 STAN. J. INT'L L. 253, 262 (2003) (“[N]o deterrent stands in the way of vulture funds to follow the incentive to litigate their debts. Vulture funds, unlike primary or institutional lenders, are immune to peer or regulatory pressure.”) (alteration in original).

${ }^{40}$ Schumacher et al., supra note 27, at 7-8.

${ }^{41}$ Allied Bank Int'l v. Banco Credito Agricola de Cartago, 757 F.2d 516 (2d Cir. 1985) [hereinafter Allied].

42 Allied Bank Int'l v. Banco Credito Agricola de Cartago, 566 F. Supp. 1440, 1442 (S.D.N.Y. 1983), rev'd, 757 F.2d 516 (2d Cir. 1985), cert. denied, 473 U.S. 934 (1985). 
moved for summary judgment. ${ }^{43}$ However, the district court held that the "act of state" doctrine ${ }^{44}$ precluded it from granting Allied Bank's motion. ${ }^{45}$ In doing so, the court opined "[e]ven where the defense of sovereign immunity does not apply, nevertheless the act of state doctrine may prevent recovery." ${ }^{46}$ While the case had been pending before the district court, all but one member of the thirty-nine bank syndicate were in favor of a proposed agreement with the Costa Rican banks to restructure the loan. ${ }^{47}$ The holdout bank subsequently directed Allied Bank to appeal the district court's decision on its behalf. ${ }^{48}$

On rehearing, the Second Circuit vacated its previous opinion, in which it had agreed with the district court that the case should be dismissed pursuant to the act of state doctrine. ${ }^{49}$ The Second Circuit concluded that because "the situs of the property was in the United States," the act of state doctrine did not apply. ${ }^{50}$ The court explained that:

The Costa Rican banks conceded jurisdiction in New York and they agreed to pay the debt in New York City in United States dollars. Allied, the designated syndicate agent, is located in the United States, specifically in New York; some of the negotiations between the parties took place in the United States. The United States has an interest in maintaining New York's status as one of the foremost commercial centers in the world. Further, New York is the international clearing center for United States dollars. In addition to other international activities, United States banks lend billions of dollars to foreign debtors each year. The United States has an interest in ensuring that creditors entitled to payment in the United States in United States dollars under contracts subject to the jurisdiction of United States courts may assume that, except under the most extraordinary circumstances, their rights will be determined

${ }^{43}$ Id. at 1442.

${ }^{44}$ See Underhill v. Hernandez, 168 U.S. 250, 252 (1897) (“[T]he courts of one country will not sit in judgment on the acts of the government of another, done within its own territory.”) (alteration in original); see also W.S. Kirkpatrick \& Co., Inc. v. Environmental Tectonics Corp., Int'l, 493 U.S. 400, 409 (1990) ("The act of state doctrine...requires that...the acts of foreign sovereigns taken within their own jurisdictions shall be deemed valId.”).

${ }^{45}$ Allied Bank Int'l v. Banco Credito Agricola de Cartago, 566 F. Supp. 1440, 1443 (S.D.N.Y. 1983), rev'd, 757 F.2d 516 (2d Cir. 1985).

${ }^{46}$ Id. at 1443.

${ }^{47}$ Allied Bank Int'l v. Banco Credito Agricola de Cartago, 757 F.2d 516, 519 (2d Cir. 1985).

${ }^{48} I d$.

${ }^{49} I d$.

${ }^{50}$ Id. at 521. 
in accordance with recognized principles of contract law. ${ }^{51}$

In addition to vacating its prior decision and reversing the district court's dismissal, the Second Circuit directed the district court to enter judgment in favor of Allied Bank. ${ }^{52}$ The Allied opinion is important because it was the first case that gave the FSIA some teeth to accompany its bark. Prior to Allied, courts had allowed foreign states to invoke the act of state doctrine as a defense in several cases involving "government activities that clearly involved commercial activities." 53 Allied signaled the dawning of a new era in sovereign debt litigation. Courts became increasingly reluctant to allow the FSIA to be frustrated by traditional sovereign immunity defenses, which resulted in a more robust application of the FSIA. Indeed, Allied not only established that "classic defenses such as sovereign immunity, the act of state doctrine or the principle of international comity were insufficient to protect a sovereign from lawsuits," ${ }^{54}$ it also validated holdout creditors. ${ }^{55}$

The second major development in sovereign default jurisprudence was the Supreme Court's decision in Republic of Argentina v. Weltover. ${ }^{56}$ In Weltover, the Supreme Court held that issuing sovereign bonds in the U.S. qualified as a commercial activity under the FSIA. ${ }^{57}$ The Court explained that a foreign state's actions are "commercial" when it acts as a private player in the market rather than as a regulator. ${ }^{58}$ After noting that "the commercial character of an act is to be determined by reference to its 'nature' rather than its 'purpose,",59 the Court held that the critical inquiry is "whether the particular actions that the foreign state performs... are the type of actions by which a private party engages in 'trade and traffic or commerce.”, 60 The Court pointed out that the bonds issued by Argentina were "in almost all respects garden-variety debt instruments."61 Disagreeing with Argentina's argument that the bonds at issue should be treated differently because they "were created by the Argentine Government to fulfill its obligations under a

${ }^{51} I d$. at $521-22$.

52 Id. at 523.

${ }^{53}$ William R. Dorsey, III, Reflections on the Foreign Sovereign Immunities Act After Twenty Years, 28 J. MAR. L. \& COM. 257, 273 (1997).

${ }^{54}$ Schumacher et al., supra note 27, at 6.

55 Schumacher et al., supra note 27, at 7; Fisch \& Gentile, supra note 28, at 1081 ("As sovereign debt litigation continued throughout the 1980s and 1990s, courts adhered to the approach in the Costa Rica cases. In particular, courts found that neither international political considerations nor the plaintiff's unwillingness to participate in a voluntary restructuring operated to bar recovery.”).

56504 U.S. 607 (1992).

${ }^{57}$ Republic of Argentina v. Weltover, 504 U.S. 607, 618-20 (1992).

${ }^{58}$ Id at 607.

${ }^{59} \mathrm{Id}$. at 614 (quoting 28 U.S.C. $\S 1603(\mathrm{~d})$ ).

${ }^{60}$ Id. (quoting BLACK'S LAW DiCTIONARY 270 (6th ed. 1990)).

${ }^{61}$ Id. at 615. 
foreign exchange program designed to address a domestic credit crisis...,”62 the Court held that it was "irrelevant why Argentina participated in the bond market in the manner of a private actor; it matters only that it did so." ${ }^{33}$

The Court further held that Argentina's default had a "direct effect" in the United States. ${ }^{64}$ The bondholders designated New York as their place of payment, ${ }^{65}$ which was their prerogative under the terms of the bonds, ${ }^{66}$ and Argentina had made interest payments to those accounts prior to declaring that it would be rescheduling the payments. ${ }^{67}$ The Court explained that "[b]ecause New York was thus the place of performance for Argentina's ultimate contractual obligations, the rescheduling of those obligations necessarily had a 'direct effect' in the United States: Money that was supposed to have been delivered to a New York bank for deposit was not forthcoming." ${ }^{68}$ As one stated, the Supreme Court's decision delivered "a definitive blow to the defense of sovereign immunity." 69 Weltover essentially foreclosed the possibility of invoking jurisdictional immunity as a defense where a foreign state issues bonds on the U.S. market, defaults, and is subsequently sued by its creditors in U.S. courts.

The final two cases discussed below pertain specifically to vulture fund litigation. Although Allied and Weltover significantly leveled the playing field for creditors by eliminating several defenses sovereign debtors had historically used to evade litigation, one important defense remained. Generally speaking, champerty laws prohibited a third party from purchasing debt for the sole purpose of bringing a lawsuit. ${ }^{70}$ Although champerty originated as a common law doctrine, it was codified by several state legislatures, including New York. ${ }^{71}$ Champerty was the last line of defense for sovereign debtors, but the vultures were circling. ${ }^{72}$ The champerty defense began to crumble following CIBC Bank \& Trust Co. v. Banco Central do Brazil. ${ }^{73}$ CIBC is especially important because it set in motion a

${ }^{62}$ Id. at 616

${ }^{63}$ Republic of Argentina v. Weltover, 504 U.S. 607, 617 (1992).

${ }^{64}$ Id. at 618.

${ }^{65} \mathrm{Id}$. at 619.

${ }^{66} I d$. at 609-610.

${ }^{67} \mathrm{Id}$. at 619.

${ }^{68} \mathrm{Id}$. (alteration in original).

${ }^{69}$ Schumacher et al., supra note 27, at 6.

70 Jonathan I. Blackman \& Rahul Mukhi, The Evolution of Modern Sovereign Debt Litigation: Vultures, Alter Egos, and Other Legal Fauna, 73 LAw \& ConTEMP. ProBs. 47, 54 (2010).

${ }^{71}$ Id. at 54; see also N.Y. Jud. Ct. Acts § 489 (McKinney 1983) (declaring that the purchase of debt "with the intent and for the purpose of bringing an action or proceeding thereon," is unlawful).

${ }^{72}$ See Blackman \& Mukhi, supra note 70, at 53 ("The most potent defense asserted by foreign states in these early cases was champerty. Had the courts broadly accepted this defense..., it could effectively have ended the industry of speculating in sovereign debt litigation.”).

73 CIBC Bank \& Trust Co. v. Banco Central do Brazil, 895 F.Supp. 660 (S.D.N.Y. 1995) [hereinafter CIBC]. 
great shift of momentum in favor of vulture funds. ${ }^{74}$

CIBC involved Brazil's default on its obligations under a debt restructuring agreement. ${ }^{75}$ When Brazil made a second attempt to restructure its debt, it gave creditors several options for converting the debt into Brady bonds, ${ }^{76}$ but later altered the terms of the agreement to require that at least thirty-five percent of creditors' debt be converted into deeply discounted bonds. ${ }^{77}$ All but two of Brazil's creditors went along quietly, one of which was the Dart family (the "Darts"). ${ }^{78}$ However, in reality, the Darts were in fact the sole holdout creditors. ${ }^{79}$ The other creditor, Banco do Brasil, was allegedly ordered by Brazilian officials not to convert approximately \$1.6 billion of the debt, thus precluding the Darts from declaring an acceleration of the debt, which would have only been possible if the Darts held a majority of the debt. ${ }^{80}$ Between 1991 and 1993, the Darts acquired Brazilian debt with a face value of approximately $\$ 1.4$ billion on the secondary market. ${ }^{81}$ Given that this debt was purchased at a sixty-five percent discount, one could imagine how the Darts could be incentivized to holdout for the full face value. $^{82}$ The Darts’ debt was subsequently assigned to CIBC Bank and Trust Company (Cayman), Ltd. (“CIBC”), which would later bring suit on behalf of the Darts. ${ }^{83}$ CIBC is not significant for what happened in the case, as the majority of CIBC's claims were ultimately dismissed, and the case eventually settled out of court. Rather, it is what did not happen in the CIBC case that makes it significant.

The defendants asserted that the assignment of debt to CIBC was a violation of New York's champerty law, ${ }^{84}$ which provided, in pertinent part, that

\footnotetext{
${ }^{74}$ Schumacher et al., supra note 27, at 7 ("CIBC v. Banco Central do Brazil was the first major litigation success by a 'vulture fund' against a sovereign debtor.”).

${ }^{75}$ Philip J. Power, Note, Sovereign Debt: The Rise of the Secondary Market and its Implication for Future Restructurings, 64 FORDHAM L. REV. 2701, 2745-46 (1996).

${ }^{76}$ Id. at 2720 ("Under a Brady Plan securitization, the bank loans owed by a single sovereign debtor are pooled together and repackaged as bonds, which are offered to the public.”). For general background information on the Brady Plan, see Id. at 2719-23.

${ }^{77} \mathrm{Id}$. at 2746.

${ }^{78}$ CIBC Bank \& Trust Co. (Cayman) Ltd. v. Banco Cent. do Brasil, 886 F. Supp. 1105, 1107 (S.D.N.Y. 1995).

${ }^{79} \mathrm{Id}$.

${ }^{80} \mathrm{Id}$.

${ }^{81}$ Power, supra note 75, at 2747.

${ }^{82} \mathrm{Id}$.

${ }^{83}$ Jessica W. Miller, Comment, Solving the Latin American Sovereign Debt Crisis, 22 U. PA. J. InT'L ECON. L. 677, 694 (2001) (“In May 1994, Bankers Trust, Bear Stearns, and Salomon Brothers, who were the previous holders-of-record of the Dart family's portion of the MYDFA debt, assigned the debt to CIBC Bank and Trust Company (Cayman), Ltd. (“CIBC”) to act on behalf of the Darts.”).

${ }^{84}$ CIBC Bank \& Trust Co. (Cayman) Ltd. v. Banco Cent. do Brasil, 886 F. Supp. 1105, 1110 (S.D.N.Y. 1995).
} 
[n]o . . . corporation or association directly or indirectly, shall solicit, buy or take an assignment of, or be in any manner interested in buying or taking an assignment of a bond, promissory note, bill of exchange, book debt, or other thing in action, or any claim or demand, with the intent and purpose of bringing an action thereon. ${ }^{85}$

The court observed that " $[t]$ o demonstrate champerty, a defendant must show that the assignment was made with the intent and purpose of bringing suit, a decidedly fact-specific inquiry." 86 Notwithstanding its acknowledgement that other courts interpreting the champerty statute had made such determinations on motions to dismiss, the court ultimately concluded "that such a finding would be inappropriate in this case." 87 The court reasoned that while it could be inferred from the complaint that one purpose behind the assignment to CIBC was to bring about a lawsuit, it could also be inferred that the Darts executed the assignment in order to benefit from the range of services a holder-of-record such as CIBC could provide them. ${ }^{88}$

$C I B C$ dealt a substantial blow to the champerty defense and further certified "holding out" as a viable option in the wake of a sovereign default. ${ }^{89}$ Elliott Associates, L.P. v. Banco de la Nacion, carried the torch the rest of the way, sounding the death knell for the champerty defense once and for all. But Elliott Associates did far more than inoculate vulture funds against the champerty defense. The pari passu clause ${ }^{90}$ strategy employed in Elliott Associates was not only innovative, it also provided the blueprint for the injunctive relief sought by the plaintiffs in the $N M L$ case, ${ }^{91}$ which is somewhat less surprising considering that NML capital is a subsidiary of Elliott Associates, L.P (“Elliott”). ${ }^{92}$

${ }^{85} \mathrm{Id}$.

${ }^{86} I d$. at 1111.

${ }^{87} \mathrm{Id}$.

${ }^{88}$ Id. ("Bear Stearns, Bankers Trust and Salomon, the predecessor holders-of-record, collected MYDFA debt payments, distributed the payments to the beneficial owners and served as agent for the Darts in matters relating to the MYDFA. Presumably, CIBC will serve these roles as well.”).

${ }^{89}$ Schumacher et al., supra note 27, at 7 ("CIBC played an important role . . . because it weakened the so called champerty defense, which, until then, prohibited the purchase of debt with the primary intent of filing a lawsuit.”).

${ }^{90}$ For more information on pari passu clauses, see generally Rodrigo Olivares-Caminal, The Pari Passu Interpretation in the Elliott Case: A Brilliant Strategy but an Awful (Mid-Long Term) Outcome?, 40 HOFSTRA L. REV. 39, 46 (2011).

${ }^{91}$ Blackman \& Mukhi, supra note 70, at 55-56.

92 See Agustino Fontevecchia, The Real Story Of How A Hedge Fund Detained A Vessel In Ghana and Even Went For Argentina's “Air Force One,” FORBES (Oct. 5, 2012, 6:50 PM), http://www.forbes.com/sites/afontevecchia/2012/10/05/the-real-story-behind-the-argentine-vesselin-ghana-and-how-hedge-funds-tried-to-seize-the-presidential-plane/; Robert Auray, Note, In Bonds We Trustee: A New Contractual Mechanism to Improve Sovereign Bond Restructurings, 82 FORDHAM L. REV. 899, 900-01 (2013). 
Elliott is a New York-based investment fund and arguably also one of the most prolific vulture funds of all time. ${ }^{93}$ In 1996, Elliott began purchasing Peruvian debt in the form of several "letter agreements," which represented the debt of a bankrupt Peruvian bank. ${ }^{94}$ All of the debt obligations were guaranteed by Peru. ${ }^{95}$ In total, Elliott held debt with a face value of approximately \$20.7 million. ${ }^{96}$ Elliott acquired this debt on the secondary market for approximately $\$ 11.4$ million, which equated to just over fifty-five percent of the face value of the debt. ${ }^{97}$ At the time Elliott purchased the debt, Peru was engaged in ongoing negotiations with its creditors to restructure the debt pursuant to the Brady Plan. ${ }^{98}$ Elliott opted-out of the restructuring, instead demanding the full face value of its debt. ${ }^{99}$ Elliott subsequently filed suit in New York state court, which was later removed to federal court. ${ }^{100}$

Following a bench trial, the district court dismissed Elliott's complaint. ${ }^{101}$ The district court held that when Elliott purchased the Peruvian debt, it did so in violation of none other than "Section 489 of the New York Judiciary Law," 102 New York’s champerty statute. On appeal, the Second Circuit summarized the district court's findings of fact as follows:

The district court noted that Elliott had no familiarity with purchasing sovereign debt until it met Newman, who together with Straus, had 'a long history' in purchasing sovereign debt and suing on it. The district court further found that Elliott intentionally 'delayed closing its purchases of Peruvian debt until the Second Circuit had clarified the litigation risks.' Moreover, the district court found that 'Elliott did not seriously consider alternatives to bringing an action,' including holding and reselling the debt, participating in Peru's privatization program, participating in the Brady Plan, or negotiating separately with the Debtors to obtain terms more favorable than the Brady terms. The

\footnotetext{
${ }^{93}$ See Auray, supra note 92, at 914 (referring to Elliott as "King of the Vultures” and noting that it is "credited with pioneering the vulture fund model in the 1990s").

${ }^{94}$ Elliott Associates, L.P. v. Banco de la Nacion, 194 F.3d 363, 366-67 (2d Cir. 1999) (alteration in original).

${ }^{95}$ Id. at 367.

${ }^{96} \mathrm{Id}$. at 366-67.

${ }^{97} \mathrm{Id}$.

${ }^{98}$ Id. at 366. See generally Ross P. Buckley, The Facilitation of the Brady Plan: Emerging Markets Debt Trading from 1989 to 1993, 21 FORDHAM INT'L L.J. 1802 (1998) (offering background information on the Brady Plan).

${ }^{99}$ Elliott Associates, 194 F.3d at 368.

${ }^{100} I d$.

${ }^{101} \mathrm{Id}$.

102 Elliott Associates, L.P. v. Republic of Peru, 12 F. Supp. 2d 328, 344 (S.D.N.Y. 1998), rev'd sub nom. Elliott Associates, L.P. v. Banco de la Nacion, 194 F.3d 363 (2d Cir. 1999).
} 
district court found that 'none of these alternatives was realistically considered by Elliott when it purchased Peruvian debt' and that '[f]rom the start, Elliott intended to sue and the testimony to the contrary was not credible.' With respect to the letters sent by Elliott to the Debtors after purchasing the debt, the court found that these letters and the other accompanying steps to negotiate 'were pretextual and never demonstrated a good faith negotiating position.' 103

The Second Circuit ultimately reversed the district court, holding that "the acquisition of a debt with intent to bring suit against the debtor is not a violation of the statute where, as here, the primary purpose of the suit is the collection of the debt acquired." ${ }^{104}$ The court further held that any intent to bring suit that Elliott may have had was merely "incidental and contingent." " 105 The court reasoned that Elliott's primary purpose for purchasing the debt was to receive its face value. ${ }^{106}$ The fact that Elliott had to resort to filing a lawsuit to achieve that purpose "was therefore incidental to its achievement." 107 Similarly, the court found that "Elliott's suit was also contingent because, had the Debtors agreed to Elliott's request for the money that the district court found Elliott was owed ... then there would have been no lawsuit. Elliott's intent to file suit was therefore contingent on the Debtors' refusal of that demand.” 108 The court concluded by acknowledging that even though the district court determined "that Elliott knew Peru would not, under the circumstances, pay in full, this does not make Elliott's intent to file suit any less contingent." 109

Not only did Elliott successfully persuade the Second Circuit to issue a death certificate for the champerty defense, ${ }^{110}$ it also secured an impressive judgment from the lower court on remand. On June 1, 2000, the district court granted summary judgment in favor of Elliott, awarding it more than $\$ 80$ million, ${ }^{111}$ which equated to over seven hundred percent of what Elliott

103 Elliott Associates, L.P. v. Banco de la Nacion, 194 F.3d 363, 368 (2d Cir. 1999).(citations omitted).

${ }^{104}$ Id. at 372.

${ }^{105}$ Id. at 379.

${ }^{106} I d$.

${ }^{107}$ Id. (internal quotations omitted).

${ }^{108}$ Id. (internal quotations omitted).

109 Elliott Associates, L.P. v. Banco de la Nacion, 194 F.3d 363, 379 (2d Cir. 1999).(citation omitted) (internal quotation marks omitted).

${ }^{110}$ See Blackman \& Mukhi, supra note 70, at 54 ("The Second Circuit's narrow reading of the champerty defense was accepted by other courts, as by the D.C. District Court in Turkmani v. Republic of Bolivia, and saved the business of speculating in defaulted sovereign debt from what would otherwise have been a major setback.”).

${ }^{111}$ Wheeler \& Attaran, supra note 39, at 257 n.18. 
originally paid for the Peruvian debt in $1996 .{ }^{112}$ If there were a vulture fund hall of fame, these feats alone would undoubtedly guarantee Elliott's admittance. ${ }^{113}$ However, it was not until Elliott sought to enforce its judgment that things really began to get interesting. The enforcement campaign that ensued was not only legendary, it would ultimately shape the landscape of contemporary vulture fund litigation.

\section{Judgment Enforcement}

Although it is clearly established from the foregoing that: 1) sovereign debtors do not enjoy blanket immunity from the jurisdiction of U.S. courts; and 2) holdout creditors who file suit in opposition to sovereign debt restructurings have a high probability of obtaining a favorable judgment, any such "successful" judgment creditor must still overcome the hurdle of enforcement. ${ }^{114}$ For example, after securing its judgment in Elliott Associates, Elliott made several unsuccessful attempts to enforce the judgment in both U.S. courts and "the courts of Belgium, Canada, England, Germany, Luxembourg, and the Netherlands." ${ }^{115}$ However, Elliott was not about to go quietly. Realizing that it was getting nowhere fast by hunting attachable property, Elliott set its sights on the financial intermediaries Peru used to make its interest payments on the restructured Brady bonds. ${ }^{116}$ Elliott's initial wave of attachment attempts may have been unsuccessful, but it nonetheless forced Peru to seek alternative intermediaries through which to make its interest payments. ${ }^{117}$

Unwilling to run the risk of attachment by using an intermediary in New York, Peru enlisted Euroclear, ${ }^{118}$ an intermediary based out of Brussels, to make its scheduled payments. ${ }^{119}$ However, before Peru could make any of its payments, Elliott miraculously secured an ex parte injunction from the Brussels Court of Appeals, effectively blocking the payment. ${ }^{120}$ The court

\footnotetext{
112 Elliott Associates, L.P. v. Banco de la Nacion, 194 F.3d 363, 367 (2d Cir. 1999) (“Elliot paid approximately \$11.4 million for these debt obligations. ...”).

${ }^{113}$ See Auray, supra note 92, at 916 ("The Elliott litigation was the first time a holdout creditor effectively used a litigation strategy to gain a disproportionate payment from a sovereign as compared to other similarly situated bondholders...The Elliott ruling solidified creditors' holdout power....”).

${ }^{114}$ See Fisch \& Gentile, supra note 28, at 1086.

115 Olivares-Caminal, supra note 90, at 43.

116 See Fisch \& Gentile, supra note 28, at 1086; see also Olivares-Caminal, supra note 90, at 43 (noting that Elliott secured attachment orders in Florida, Maryland, New York, and Washington, D.C.).

117 See Wheeler \& Attaran, supra note 39, at 257; see also Fisch \& Gentile, supra note 28, at 1086.

${ }^{118}$ See Blackman \& Mukhi, supra note 70, at 56 n.47.

${ }^{119}$ Michael Bradley et al., The Market Reaction to Legal Shocks and Their Antidotes: Lessons from the Sovereign Debt Market, 39 J. LEGAL STUD. 289, 292 (2010).

${ }^{120}$ William W. Bratton, Pari Passu and A Distressed Sovereign's Rational Choices, 53 EMORY L.J. 823, 824 (2004).
} 
agreed with Elliott that the pari passu ${ }^{121}$ clause contained in the debt agreement entitled Elliott to a pro rata share of any payments Peru made to creditors. ${ }^{122}$ Finding itself between a rock and a hard place, Peru had no choice but to succumb to the will of the vultures circling overhead. To do otherwise would have landed Peru in default on its obligations to the holders of its Brady bonds. ${ }^{123}$ On September 29, 2000, Peru settled with Elliott for $\$ 56.3$ million, "representing a nearly 500 percent return on Elliott's initial investment." 124

In the aftermath of Elliott Associates, vulture funds have employed the pari passu strategy and other innovative techniques against sovereign debtors. ${ }^{125}$ Given the mixed results in subsequent cases, prior to $N M L$, it appeared that Elliott Associates may have been the high-water mark for judgment enforcement in vulture fund litigation. ${ }^{126}$ Although the proper interpretation of a pari passu clause is not the focus of this Note, the ratable payment interpretation adopted by the Brussels court is relevant to the injunctions imposed by the district court in NML. While the treatment of the pari passu clause by the Brussels court in Elliott Associates appears strikingly similar to the treatment of the pari passu clause at issue in $N M L$, closer inspection reveals a subtle, yet important distinction, which will be discussed in greater detail below.

\section{The Foreign Sovereign Immunities Act}

Sovereign immunity is a well-established doctrine of international law, at the core of which is the principle that where appropriate, one state will not be subject to the jurisdiction of another state's domestic courts. ${ }^{127}$ Prior to the inception of the FSIA, foreign states enjoyed absolute immunity from the jurisdiction of U.S. courts. ${ }^{128}$ This principle was first recognized by the Supreme Court in Schooner Exchange v. McFaddon, ${ }^{129}$ wherein Chief Justice Marshall acknowledged the concept of sovereign immunity as being a basic

\footnotetext{
${ }^{121}$ For background information on pari passu clauses, see G. Mitu Gulati \& Kenneth N. Klee, Sovereign Piracy, 56 Bus. Law. 635, 636 (2001).

122 See Lee C. Buchheit \& Jeremiah S. Pam, The Pari Passu Clause in Sovereign Debt Instruments, 53 EMORY L.J. 869, 879 (2004).

${ }^{123}$ Bradley et al., supra note 119, at 294.

${ }^{124}$ Wheeler \& Attaran, supra note 39, at 258.

${ }^{125}$ Bradley et al., supra note 119, at 295.

126 See Blackman \& Mukhi, supra note 70, at 57 ("For whatever reason, the Elliott pari passu strategy seems to have receded from the forefront of creditor enforcement strategies."); see also Bradley et al., supra note 119, at 295 ("While sovereign have succeeded in defending some of these cases, they have had to settle others.”); Auray, supra note 92, at 916 ("Elliott is now utilizing similar tactics in its efforts to collect on defaulted Argentine bonds.”).

${ }^{127}$ H.R. Rep. No. 94-1487, at 8 (1976).

128 The Schooner Exch. v. McFaddon, 11 U.S. 116, 144 (1812).

${ }^{129}$ See Id.
} 
tenet of international law. ${ }^{130}$ However, following World War II, the inequity of absolute immunity became readily apparent. ${ }^{131}$ Under absolute immunity, a foreign state was able to invoke immunity against civil liability, even where the conduct which gave rise to the liability occurred while the foreign state was engaged in a purely commercial activity. ${ }^{132}$ Thus, absolute immunity allowed foreign states to have their cake and eat it too. It essentially gave foreign states a license to engage in commercial activities without having to give so much as a second's thought to any potential liabilities that may flow from their conduct. ${ }^{133}$

The shift away from absolute immunity gained substantial momentum in 1952, with the dispatch of the infamous "Tate Letter." ${ }^{134}$ In the Tate Letter, the U.S. Department of State ("State Department") proclaimed that it was abandoning the doctrine of absolute immunity in favor of the restrictive theory of sovereign immunity. ${ }^{135}$ The State Department reasoned that continuing to extend absolute immunity to foreign states would be inappropriate, principally because the participation of foreign states in private commerce was becoming more and more prevalent, which had the unjust effect of leaving private actors with no legal recourse for harms caused by foreign states. ${ }^{136}$ Moreover, the State Department pointed out that restricting a foreign state's immunity to liabilities arising out of its public acts, but not its private acts, had become the predominant practice among sovereigns in the global community. ${ }^{137}$

Although the Tate Letter succeeded in swinging the pendulum away from absolute immunity and towards the restrictive theory, it had certain shortcomings which left much to be desired for prospective plaintiffs. ${ }^{138}$ Among the most significant was that it was essentially a bark with no bite. While the restrictive theory allowed plaintiffs to pierce the veil of absolute immunity, it did nothing in the way of providing a mechanism by which a judgment against a foreign state could be satisfied. ${ }^{139}$ To address this issue and several others, Congress enacted the FSIA in 1976, ${ }^{140}$ which symbolized a long-overdue paradigm shift towards holding foreign states accountable for

\footnotetext{
${ }^{130}$ Id. at 137.

${ }^{131}$ Lippert, supra note 30, at 10.

${ }^{132}$ Id. at 10 n.70.

${ }^{133} \mathrm{Id}$. at 10.

${ }^{134}$ See Letter from Jack B. Tate, Acting Legal Adviser, U.S. Dept. of State, to Acting U.S. Attorney General Philip B. Perlman, May 19, 1952, in 26 Dep’t State Bull. 984-85 (1952) (hereinafter “Tate Letter").

${ }^{135} \mathrm{Id}$. at 985 .

${ }^{136} \mathrm{Id}$.

${ }^{137} \mathrm{Id}$.

${ }^{138}$ Lippert, supra note 30, at 10-11.

${ }^{139} \mathrm{Id}$. at 11.

14028 U.S.C. $\S \S 1602-11$ (2014).
} 
liabilities arising out of their commercial activities. ${ }^{141}$

The FSIA prescribes the "sole and exclusive standards to be used in resolving questions of sovereign immunity raised by foreign states before federal and state courts in the United States." ${ }^{142}$ As noted above, one purpose of the FSIA was to codify what was known as the "restrictive" theory of sovereign immunity. ${ }^{143}$ The restrictive theory provides a foreign state with immunity against claims arising out of its public or sovereign acts, but subjects a foreign state to the jurisdiction of U.S. courts for claims arising out of its "commercial or private acts." "444 Under the FSIA, "foreign states," including their "political subdivisions" and "agencies or instrumentalities," 145 enjoy a presumption of immunity from the jurisdiction of U.S. courts. ${ }^{146}$ To rebut this presumption, a plaintiff must invoke one of the exceptions set forth in Section 1605. ${ }^{147}$

Where one of the exceptions is applicable, a foreign state is subject to jurisdiction "in the same manner and to the same extent as a private individual." "148 These exceptions include, inter alia, instances in which a foreign state "has waived its immunity either explicitly or by implication," as well as certain claims predicated on the foreign state's commercial activities. ${ }^{149}$ The FSIA defines "commercial activity" as "either a regular course of commercial conduct or a particular commercial transaction or act," and provides that "[t]he commercial character of an activity shall be determined by reference to the nature of the course of conduct or particular transaction or act, rather than by reference to its purpose.” 150

Similarly, the FSIA provides that property in the United States belonging to a foreign state "shall be immune from attachment arrest and execution except as provided" by the statute. ${ }^{151}$ Thus, a prospective plaintiff seeking to bring an action against a foreign state will travel two roads with the FSIA: (1) the plaintiff must establish the applicability of one of the exceptions to jurisdictional immunity provided in Section 1605; and (2) upon obtaining a judgment, the plaintiff must establish the applicability of one of the exceptions enumerated in Section 1610 before it may levy on any property in the United States belonging to the foreign state. ${ }^{152}$

\footnotetext{
${ }^{141}$ See Id. at § 1602.

${ }^{142}$ H.R. Rep. No. 94-1487, at 12 (1976).

${ }^{143} \mathrm{Id}$. at 7.

${ }^{144} \mathrm{Id}$. at 8.

14528 U.S.C. $\S 1603$.

14628 U.S.C. § 1604.

14728 U.S.C. § 1605(a).

14828 U.S.C. $\S 1606$.

14928 U.S.C. § 1605.

15028 U.S.C. § 1603(d).

15128 U.S.C. § 1609.

15228 U.S.C. $\S 1604-10$.
} 


\section{Attachment and Execution of Foreign Assets}

Without question, the least difficult aspect of bringing a claim against a sovereign debtor is successfully establishing jurisdiction and obtaining a favorable judgment. ${ }^{153}$ The toughest challenge a creditor faces is enforcement of its judgment. ${ }^{154}$ The FSIA contains a strong and clear statutory presumption against attachment and execution of property belonging to a foreign state, which is embodied in Section 1609 of the statute:

Subject to existing international agreements to which the United States is a party at the time of enactment of this Act the property in the United States of a foreign state shall be immune from attachment arrest and execution except as provided in sections 1610 and 1611 of this chapter. ${ }^{155}$

Thus, unless a judgment creditor can avail itself of a treaty or other international agreement to which the United States and the sovereign debtor are both signatories, it is limited to enforcing its judgment pursuant to the provisions of the FSIA. ${ }^{156}$ Generally speaking, under the FSIA, a judgment creditor may execute against a foreign state's property only to the extent that: (1) such property is located in the United States; (2) such property is used for a commercial activity; and (3) one of the exceptions enumerated under Section 1610 is applicable. ${ }^{157}$ In the context of sovereign default, there are two key exceptions available: where a foreign state has waived "its immunity from attachment in aid of execution or from execution either explicitly or by implication," 158 and where "the property is or was used for the commercial activity upon which the claim is based." 159

The commercial activity exception applicable to a foreign state is found in Section 1610(a)(2) and provides that a foreign state's property may be attached only if "the property is or was used for the commercial activity upon which the claim is based...." ${ }^{160}$ Thus, even if a prevailing plaintiff is fortunate enough to identify some property in the U.S. belonging to the foreign state, if that property was not used for, or otherwise connected with, the

\footnotetext{
153 See Joseph W. Dellapenna, Refining the Foreign Sovereign Immunities Act, 9 WILLAMETTE J. INT'L L. \& DisP. RES. 57, 75 (2001).

${ }^{154}$ See Lippert, supra note 30, at 12 n.86; see also Working Group of the American Bar Association, Reforming the Foreign Sovereign Immunities Act, 40 COLUM. J. TRANSNAT'L L. 489, 581 (2002) ("The execution immunity provisions of the [FSIA], and particularly section 1610, are generally regarded as among the most confusing and ineffectual in the statute.”) (alteration in original). 15528 U.S.C. § 1609.

${ }^{156} \mathrm{Id}$.

15728 U.S.C. $\S 1609-10$.

15828 U.S.C. § $1610(\mathrm{a})(1)$.

15928 U.S.C. $\S 1610(a)(2)$.

${ }^{160}$ See 28 U.S.C. § 1610(a)(2)
} 
commercial activity which gave rise to the underlying claim, it is immune from attachment or execution. ${ }^{161}$ Commentators have pointed out that Section 1610(a)(2) "produces an extremely restrictive regime for enforcement of judgments against foreign sovereigns." 162 This is because it would be extremely rare for a foreign state to have such property in the United States, if at all. ${ }^{163}$ Thus, it should come as to no surprise that judgment creditors faced with such grim prospects of recovery under the FSIA would explore alternative remedies.

\section{Recognition and Enforcement of U.S. Judgments Abroad}

Where a sovereign debtor has no attachable assets in the U.S., a judgment creditor can attempt to satisfy its judgment by seeking to have it recognized by a court in a foreign jurisdiction where the sovereign debtor has attachable assets. ${ }^{164}$ However, there is currently no enforcement mechanism available to compel foreign courts to recognize U.S. judgments. ${ }^{165}$ Because the United States is not currently a signatory to any treaty or convention guaranteeing the recognition and enforcement of its judgments abroad, ${ }^{166} \mathrm{a}$ judgment creditor seeking to enforce its judgment in another country is at the mercy of that country's domestic laws and "the principles of comity, reciprocity and res judicata." ${ }^{167}$ Accordingly, this alternative is not for the faint of heart. As one commentator highlights, "[n]ot only will one encounter all the usual difficulties in executing American judgments abroad, but one will also be limited by any restrictions on the execution of judgments against

161 See Id.

${ }^{162}$ Working Group of the American Bar Association, Reforming the Foreign Sovereign Immunities Act, 40 Colum. J. TRANSNAT’L L. 489, 584 (2002).

${ }^{163} \mathrm{Id}$.

164 See Autotech Technologies LP v. Integral Research \& Dev. Corp., 499 F.3d 737, 751 (7th Cir. 2007) ("If assets exist in another country, the person seeking to reach them must try to obtain recognition and enforcement of the U.S. judgment in the courts of that country. If that effort is successful, then those courts can use their powers to assure enforcement of the judgment.”); see also Olivares-Caminal, supra note 90, at 40 (“Once a favorable ruling has been obtained, a creditor can attempt to execute property in the jurisdiction of the issuer or abroad. . . .”); see also Schumacher et al., supra note 27, at 2 ("In recent years, more than half of all pending cases involved at least one attempt to seize sovereign assets abroad.”).

165 See Panagiota Kelali, Provisional Relief in Transnational Litigation in the Internet Era: What Is in the US Best Interest?, 24 J. MARSHALL J. COMPUTER \& INFO. L. 263, $290-91$ (2006).

166 See U.S. Department of State Bureau of Consular AfFairs, Enforcement of Judgments, available at http://travel.state.gov/content/travel/english/legal-considerations/

judicial/enforcement-of-judgments.html (last visited Sep. 17, 2014) (“There is no bilateral treaty or multilateral convention in force between the United States and any other country on reciprocal recognition and enforcement of judgments.”).

167 U.S. Department of State Bureau of Consular Affairs, Enforcement of Judgments, available at http://travel.state.gov/content/travel/english/legal-considerations/judicial/

enforcement-of-judgments.html (last visited Sep. 17, 2014). 
foreign states under the law of the state where execution is sought." ${ }^{168}$ Indeed, some countries simply refuse to recognize any foreign judgments unless compelled to do so by treaty or convention. ${ }^{169}$

Notwithstanding the fact that the restrictive theory of sovereign immunity has been widely accepted by the international community, its interpretation and application has been far from uniform. ${ }^{170}$ But, this cuts both ways. While some states have historically been reluctant to enforce U.S. judgments, ${ }^{171}$ other countries — such as Brazil, France, Germany, and Italydo so quite frequently. ${ }^{172}$ In fact, some countries not only recognize U.S. judgments regularly, but have also enacted sovereign immunity regimes which are less protective of foreign property. ${ }^{173}$ For example, the U.K.'s State Immunity Act of $1978^{174}$ ("SIA"), provides that where a foreign state has expressly waived its immunity from execution, any property in the U.K. belonging to the foreign state may be subject to execution, even if the property: 1) does not have a connection to the underlying claim; or 2) is not used for a commercial activity. ${ }^{175}$ Absent express waiver, the SIA's commercial activity exception is still more relaxed than that of the FSIA. ${ }^{176}$ The SIA's version of the commercial activity exception merely requires that the property be "in use or intended for use for commercial purposes," 177 without any further requirement of a nexus between the property and the underlying claim. ${ }^{178}$ However, it would appear that the only caveat to this is

${ }^{168}$ Dellapenna, supra note 153 at 77-78.

169 See Samuel P. Baumgartner, How Well Do U.S. Judgments Fare in Europe?, 40 GEO. WASH. INT'L L. REV. 173, 184 (2008).

170 See J. Patrick Kelly, The Twilight of Customary International Law, 40 VA. J. INT'L L. 449, 468 (2000); see also George K. Foster, Collecting from Sovereigns: The Current Legal Framework for Enforcing Arbitral Awards and Court Judgments Against States and Their Instrumentalities, and Some Proposals for Its Reform, 25 ARIZ. J. InT'L \& COMP. L. 665, 671 (2008); see also Joanne Foakes \& Elizabeth Wilmshurst, UN Convention on Jurisdictional Immunities of States and Their Property, 7 Bus. L. INT'L 105, 110 (2006) ("But the practice of states in giving immunity to [other] states has not been consistent.”) (alteration in original).

${ }^{171}$ See Panagiota Kelali, Comment, Provisional Relief in Transnational Litigation in the Internet Era: What Is in the US Best Interest?, 24 J. MARSHALL J. COMPUTER \& INFO. L. 263, 291 (2006); see also Foakes \& Wilmshurst, supra note 170, at 110 (noting that "socialist state-trading countries" such as "the old Soviet Union and China" have historically adhered to the principles of absolute immunity for foreign states).

${ }^{172}$ See Maria Angela Jardim de Santa Cruz Oliveira, Recognition and Enforcement of United States Money Judgments in Brazil, 19 N.Y. INT'L L. REV. 1, 4 (2006) ("Brazil has had a tradition of confirming foreign country judgments almost automatically.”); see also Baumgartner, supra note 169 , at 998.

173 See Foster, supra note 170, at 684-87.

174 See State Immunity Act, 1978, c. 33 (Eng.).

${ }^{175} I d$. at $\S 2-3$.

${ }^{176} I d$. at $\S 4$.

177 Id. at $\S 13$.

${ }^{178}$ Cf. 28 U.S.C. § 1610(a)(2) (2014) (requiring a nexus between the property sought to be levied on and the commercial activity which gave rise to the underlying claim). 
that the sovereign debtor must be a signatory to the European Convention on State Immunity, ${ }^{179}$ or must it?

Interestingly enough, not only have the plaintiffs in $N M L$ gained notoriety from the Second Circuit's groundbreaking opinion, but also for the substantial impact they have had on English law. On May 10, 2006, Judge Thomas Griesa awarded NML Capital summary judgment ${ }^{180}$ against Argentina in the amount of approximately $\$ 248$ million. ${ }^{181}$ Shortly thereafter, NML Capital sought to enforce its judgment in the U.K. ${ }^{182}$ Reversing a lower court decision, the Court of Appeal held that English courts lacked jurisdiction to recognize and enforce the New York judgment. ${ }^{183}$ On appeal, Argentina argued that recognition and enforcement of the New York judgment fell outside of the scope of the "commercial transactions" exception ${ }^{184}$ of the SIA. ${ }^{185}$ Surprisingly, the U.K. Supreme Court agreed. ${ }^{186}$ It reasoned that while the claims underlying the New York judgment were undoubtedly commercial in nature, the action brought by NML in the English courts pertained solely to recognition and enforcement of the New York judgment, rather than to the actual bonds. ${ }^{187}$ Thus, the court held that because the recognition and enforcement proceedings were beyond the scope of the exception, NML was unable to avail itself of the commercial transaction exception. ${ }^{188}$ However, the court went on to find that English courts had proper jurisdiction over Argentina due to an express waiver contained in the language of the bond contracts. ${ }^{189}$

The final-and most significant—issue decided by the court was whether Section 31(1) of the Civil Jurisdiction and Judgments Act $1982^{190}$ (the "CJJA") should be interpreted as supplementing the immunity provisions of the SIA, or whether it "provided a comprehensive alternative framework for the recognition and enforcement" of foreign judgments in English courts. ${ }^{191}$ Section 31(1) of the CJJA stated:

\footnotetext{
${ }^{179}$ State Immunity Act, 1978, c. 33, § 4 (Eng.).

180 The judgment was predicated on the same default by Argentina which was at issue in NML.

${ }^{181}$ NML Capital, Ltd. v. Republic of Argentina, 2006 WL 1294853 (S.D.N.Y. May 10, 2006).

${ }^{182}$ Charles Proctor, Argentina and the Vulture Funds - No Hiding Place?, 27 B.F.L.R. 735, 736 (2012).

${ }^{183}$ Id. at 736-37.

184 State Immunity Act, 1978, c. 33, § 4 (Eng.).

185 Proctor, supra note 182, at 737-38.

${ }^{186}$ Id. at 738.

${ }^{187} \mathrm{Id}$.

${ }^{188} \mathrm{Id}$.

${ }^{189} \mathrm{Id}$. at 739 .

${ }^{190}$ Civil Jurisdiction and Judgments Act 1982, 1982 c. 27, § 31 (Eng.). See also Proctor, supra note 182, at 739 ("The 1982 Act was passed to give effect to the Brussels Convention on Jurisdiction and the Enforcement of Judgment in Civil and Commercial Matters 1968, but the scope of the 1982 Act was not limited to the States that were parties to that convention.”).

${ }^{191}$ Proctor, supra note 182, at 739.
} 
(1) A judgment given by a court of an overseas country against a state other than the United Kingdom or the state to which that court belongs shall be recognised [sic] and enforced in the United Kingdom if, and only if-(a) it would be so recognised [sic] and enforced if it had not been given against a state; and (b) that court would have had jurisdiction in the matter if it had applied rules corresponding to those applicable in such matters in the United Kingdom in accordance with sections 2 to 11 of the State Immunity Act 1978. ${ }^{192}$

In overturning the Court of Appeal, the U.K. Supreme Court unanimously agreed that Section 31 established an independent mechanism for recognizing and enforcing foreign judgments in English courts. ${ }^{193}$ Applying the test to the New York judgment, the court held that it was in fact recognizable and enforceable in English courts. ${ }^{194}$

The NML proceedings in the U.K. were significant for several reasons, two of which are particularly relevant here. First, they are a prime example of the type of arduous legal battle a judgment creditor could potentially find itself in when attempting to enforce a U.S. judgment in a foreign court. Although NML ultimately prevailed in the U.K., it took nearly five years and an appeal all the way to the U.K. Supreme Court. ${ }^{195}$ This substantiates the point that enforcement campaigns in foreign courts are often rife with great difficulty and uncertainty, and thus should not be embarked on haphazardly. ${ }^{196}$ Second, these proceedings demonstrate that despite the potential obstacles that await, attempting to have a judgment enforced in a foreign court can be a valid option, ${ }^{197}$ especially where all other enforcement options available under the FSIA have been exhausted. Given the narrow range of enforcement options available under the FSIA and the rarity of attachable foreign assets in the United States, after years of litigation and millions of dollars in attorneys' fees, creditors like NML often find themselves holding what amounts to a nominal judgment. ${ }^{198}$ Thus, it is

192 Civil Jurisdiction and Judgments Act 1982, 1982 c. 27, § 31 (Eng.).

193 Proctor, supra note 182, at 740-41.

${ }^{194}$ Id. at 741.

195 UK Supreme Court: Sovereign Immunity Judgment, NORTON RosE FULBRIGHT, http://www.nortonrosefulbright.com/knowledge/publications/54793/uk-supreme-court-sovereignimmunity-judgment (August 2011).

196 See Foster, supra note 170, at 666-67.

197 See Baumgartner, supra note 169, at 998 (pointing out that "there are a number of countries that quite liberally recognize and enforce judgments from the United States[]”).

${ }^{198}$ See Saloni Kantaria, Looks Can Be Deceiving: Holdout Litigation Under the Foreign Sovereign Immunities Act, 10 Engage: J. Federalist SoC'y Prac. Groups 26, 30 (2009) (“Although the initial impression of the FSIA is that it is a suitable repayment vehicle for vulture creditors, this is not so, due to the dualism of immunity and nexus requirements within provisions 1605 and 1610. 
unsurprising that judgment creditors are increasingly willing to assume the risks associated with litigating in foreign courts, or that they are pursuing more creative approaches to satisfying their judgments.

\section{NML CAPITAL, LTD. V. REPUBLIC OF ARGENTINA}

The plaintiffs in NML consist of various hedge funds and other investors specializing in distressed sovereign debt, including Elliott Associates, who purchased Argentine bonds on the secondary market. ${ }^{199}$ Argentina began issuing the bonds in 1994 pursuant to a Fiscal Agency Agreement ("FAA"). ${ }^{200}$ The FAA contained a pari passu clause, which provided that:

[t]he Securities will constitute...direct, unconditional, unsecured and unsubordinated obligations of [Argentina] and shall at all times rank pari passu without any preference among themselves. The payment obligations of [Argentina] under the Securities shall at all times rank at least equally with all its other present and future unsecured and unsubordinated External Indebtedness ... ${ }^{201}$

In its opinion, the Second Circuit refers to the second sentence of the clause as the "Equal Treatment Provision."202 Additionally, the bonds were governed by New York law, and the FAA provided for jurisdiction in "any state or federal court in The City of New York."203

After defaulting on the FAA bonds in 2001, Argentina attempted to restructure the debt by offering Exchange Bonds to FAA bondholders; first in 2005 and again in 2010. ${ }^{204}$ Creditors who accepted the Exchange Bonds received between twenty-five and twenty-nine cents on every dollar they had

These provisions make the FSIA unduly restrictive and provide substantial protection to sovereigns."); see also Lippert, supra note 30, at 14 ("Satisfying the section 1610 exceptions for execution is a very difficult task, especially establishing a link between attachable commercial property and the underlying claim.”); see also Dorsey, supra note 53, at 269 (“Of course, in most cases there are no such commercial assets of a foreign state in the United States.”); see also Schumacher et al., supra note 27, at 3 ("The costs of litigation are hard to quantify, but all available evidence suggests that they are increasing. ... The duration of cases has also increased, to an average of 6 years.”).

199 NML Capital, Ltd. v. Republic of Argentina, 699 F.3d 246, 251 (2d Cir. 2012) cert. denied, 134 S. Ct. 201, 187 L. Ed. 2d 256 (U.S. 2013).

${ }^{200} \mathrm{Id}$.

${ }^{201} I d$. (alteration in original).

${ }^{202} I d$.

${ }^{203}$ Id. at 253-254.

204 NML Capital, Ltd. v. Republic of Argentina, 699 F.3d 246, 251 (2d Cir. 2012) cert. denied, 134 S. Ct. 201, 187 L. Ed. 2d 256 (U.S. 2013)... 
originally paid for the defaulted bonds. ${ }^{205}$ In 2005, Argentina went to great lengths to compel creditors to accept the Exchange Bonds. In the prospectus for the Exchange Bonds, under the section titled "Risks of Not Participating in [the] Exchange Offer," Argentina declared:

Existing defaulted bonds eligible for exchange that are not tendered may remain in default indefinitely. As of June 30, 2004, Argentina was in default on approximately U.S. $\$ 102.6$ billion of its public indebtedness. . . . The Government has announced that it has no intention of resuming payment on any bonds eligible to participate in [the] exchange offer...that are not tendered or otherwise restructured as part of such transaction. Consequently, if you elect not to tender your bonds in an exchange offer there can be no assurance that you will receive any future payments in respect of your bonds. ${ }^{206}$

Also in 2005, Argentina enacted the "Lock Law," just in case there remained any uncertainty with respect to its intended treatment of the FAA bonds. ${ }^{207}$ The Lock Law declared that: "[t]he national Executive Power may not, with respect to the bonds..., reopen the swap process established in the [2005 exchange offer]...The national State shall be prohibited from conducting any type of in-court, out-of-court or private settlement with respect to the bonds...," and that "[t]he national Executive Power must . . . remove the bonds ... from listing on all domestic and foreign securities markets and exchanges."208

Argentina's efforts to push the Exchange Bonds were largely successful. The 2005 offer netted a seventy-six percent participation rate. ${ }^{209}$ The 2010 offering was "substantially identical to the 2005 offering," at the end of which Argentina had restructured more than ninety-one percent of its external debt. ${ }^{210}$ The plaintiffs in $N M L$ represent the remaining holdout creditors who refused to participate in either of the restructurings. ${ }^{211}$ Collectively, these creditors hold approximately $\$ 4$ billion in Argentine debt. ${ }^{212}$ "[The creditors] sued Argentina on the defaulted bonds at various

\footnotetext{
205 Id at 252.

${ }^{206} I d$. (alteration in original).

${ }^{207} \mathrm{Id}$.

208 NML Capital, Ltd. v. Republic of Argentina, 699 F.3d 246, 252 (2d Cir. 2012) cert. denied, 134 S. Ct. 201, 187 L. Ed. 2d 256 (U.S. 2013).

${ }^{209} \mathrm{Id}$.

${ }^{210} I d$. at 253.

211 Second Circuit Affirms Injunction Requiring Argentina to Pay on Defaulted Bonds, Rejects Immunity Arguments, 107 AM. J. INT'L L. 221, 222 (2013).

${ }^{212} I d$.
} 
points from 2009 to 2011, alleging breach of contract and seeking injunctive relief, including specific performance of the Equal Treatment Provision.”213 The creditors alleged that Argentina violated the Equal Treatment Provision of the FAA by regularly making payments to holders of the Exchange Bonds, while ceasing all payments to holders of the FAA bonds. ${ }^{214}$

\section{A. Legality of the NML Injunctions Vis-à-Vis the FSIA}

As one commentator correctly points out, the novelty of the $N M L$ case is not derived from the district court's interpretation of the bonds' pari passu clause, but rather from the remedial issues raised by the injunctions imposed upon Argentina. ${ }^{215}$ The most patent of these issues is whether the district court exceeded the scope of its remedial powers under the FSIA when it issued permanent injunctions against Argentina. The decision also raises interesting questions about the effect of such injunctions on third parties. ${ }^{216}$ Rule 65 of the Federal Rules of Civil Procedure empowers a court to enjoin the conduct of a third party, to the extent that such conduct violates an injunction of which the third party has notice, ${ }^{217}$ but does Rule 65 remain as far-reaching where the enjoined party is a foreign state? This section will explore these issues and others, as well as the tension between the $N M L$ injunctions and the FSIA.

The district court's injunctions in NML can be broken down into two key components. First, the district court enjoined Argentina from making any further payments to Exchange bondholders without simultaneously making ratable payments to the plaintiffs. ${ }^{218}$ The district court explained the ratable payment formula as follows:

The obligation to plaintiffs under the February 23, 2012 Injunctions accrues whenever Argentina 'pays any amount due' under the terms of the Exchange Bonds. The next time this will occur will be in December 2012, when Argentina is scheduled to make interest payments on the Exchange Bonds of about \$3.14 billion: \$42 million on December 2, \$3 billion on December 15, and \$100 million on December 31. When

\footnotetext{
213 NML Capital, Ltd. v. Republic of Argentina, 699 F.3d 246, 253 (2d Cir. 2012) (alteration in original) (emphasis added).

${ }^{214} I d$. at 251-52.

215 Zamour, supra note 1, at 56.

${ }^{216} I d$.

${ }^{217}$ Fed. R. Civ. P. 65(d)(2); Regal Knitwear Co. v. N.L.R.B., 324 U.S. 9, 14-15 (1945); K.C. ex rel. Africa H. v. Shipman, 716 F.3d 107, 115 (4th Cir. 2013); F.T.C. v. Leshin, 618 F.3d 1221, $1235-$ 36 (11th Cir. 2010); Hershey v. ExxonMobil Oil Corp., No. 12-3309, 2013 WL 6571674, at*4 (10th Cir. Dec. 16, 2013); S.E.C. v. Homa, 514 F.3d 661, 674 (7th Cir. 2008).

218 NML Capital, Ltd. v. Republic of Argentina, No. 08-CIV-6978-TPG, 2012 WL 5895786, at *34, (S.D.N.Y. Nov. 21, 2012), aff'd, 727 F.3d 230 (2d Cir. 2013).
} 
this occurs, Argentina will be required to make a 'Ratable Payment' to plaintiffs. Assuming that Argentina pays 100\% of what is then due on the Exchange Bonds, this is the 'Payment Percentage'....Argentina would be required to pay $100 \%$ 'multiplied by the total amount currently due' to plaintiffs. $^{219}$

Because Argentina had previously defaulted on the FAA bonds, and the remedy for default under the terms of the bonds was acceleration, this ruling essentially means that upon making 100 percent of the next payment due to the Exchange bondholders, Argentina would be required to pay the plaintiffs 100 percent of the accelerated principal, plus interest, which equated to approximately $\$ 1.33$ billion. ${ }^{220}$

Second, the district court enjoined Argentina from "altering or amending the processes or specific transfer mechanisms by which it makes payments on the Exchange Bonds." ${ }^{221}$ In January 2012, the district court issued a temporary restraining order which enjoined Argentina:

from altering or amending the processes or specific transfer mechanisms (including the use of specific firms) by which it makes payments due to holders of bonds or other securities issued pursuant to its 2005 and 2010 exchange offers, including without limitation by using agents, financial intermediaries and financial vehicles other than those used at the time of this Order. ${ }^{222}$

In February 2012, the district court issued a permanent injunction and ordered Argentina's specific performance pursuant to the Equal Treatment Provision of the pari passu clause, requiring Argentina to make "ratable payments" to FAA bondholders any time payments were made to holders of the Exchange Bonds. ${ }^{223}$ The district court further ordered copies of the injunctions to be disseminated to "all parties involved, directly or indirectly, in advising upon, preparing, processing, or facilitating any payment on the Exchange Bonds," ${ }^{224}$ which, by virtue of Rule 65(d)(2), was intended to give the injunctions teeth. ${ }^{225}$ As the Second Circuit explained:

${ }^{219} I d$. at $* 2$.

${ }^{220} \mathrm{Id}$.

${ }^{221}$ Order at 5, NML Capital, Ltd. v. Republic of Argentina, No. 08 Civ. 6978 (TPG) (S.D.N.Y. Feb. 23, 2012).

222 NML Capital, Ltd. v. Republic of Argentina, 699 F.3d 246, 254 (2d Cir. 2012).

${ }^{223} \mathrm{Id}$.

${ }^{224}$ Id. at 255.

${ }^{225} \mathrm{Id}$. 
These could include Argentina's agent-banks located in New York that hold money in trust for the exchange bondholders and process payments to them under the terms of those bonds. Under Rule 65(d)(2), parties, their 'officers, agents, servants, employees, and attorneys,' as well as 'other persons who are in active concert or participation with' them, are bound by injunctions. Furthermore, the Injunctions expressly prohibit Argentina's agents from aiding and abetting any violation of this ORDER, including any further violation by [Argentina] of its obligations under [the Equal Treatment Provision], such as any effort to make payments under the terms of the Exchange Bonds without also concurrently or in advance making a ratable payment to [plaintiffs]. ${ }^{226}$

According to the district court, an equitable remedy was justifiable under the circumstances, because

[a]bsent equitable relief, [plaintiffs] would suffer irreparable harm because the Republic's payment obligations to [plaintiffs] would remain debased of their contractuallyguaranteed status, and [plaintiffs] would never be restored to the position [they were] promised that [they] would hold relative to other creditors in the event of default. ${ }^{227}$

Moreover, the court opined that there was no adequate legal remedy available "because [Argentina] has made clear-indeed, it has codified in [the Lock Law] and [the Lock Law Suspension] - its intention to defy any money judgment issued by this Court." 228 The court observed that "if there was any belief that the [Argentina] would honestly pay its obligations, there wouldn't be any need for these kinds of" provisions in the injunctions. ${ }^{229}$ Additionally, the court noted that Argentina "has the financial wherewithal to meet its commitment of providing equal treatment to [plaintiffs] and [to the exchange bondholders]." ${ }^{230}$ The court concluded that:

[t]he public interest of enforcing contracts and upholding the rule of law will be served by the issuance of th[ese] [Injunctions], particularly here, where creditors of [Argentina] have no recourse to bankruptcy regimes to

${ }^{226} I d$. (alteration in original) (internal quotations omitted).

${ }^{227} \mathrm{Id}$.

${ }^{228}$ NML Capital, Ltd. v. Republic of Argentina, 699 F.3d 246, 255 (2d Cir. 2012).

${ }^{229}$ Id. at 256 (alteration in original) (quoting the district court).

${ }^{230} \mathrm{Id}$. (quoting the district court). 
protect their interests and must rely upon courts to enforce contractual promises. No less than any other entity entering into a commercial transaction, there is a strong public interest in holding the Republic to its contractual obligations. $^{231}$

In its opinion dated October 26, 2012, the Second Circuit affirmed the district court's injunctions, but remanded the case for clarification "as to how the injunctions' payment formula is intended to function and how the injunctions apply to third parties such as intermediary banks." ${ }^{232}$ In doing so, the Second Circuit made some interesting observations. First, it held that monetary damage are an "ineffective remedy" because "Argentina will simply refuse to pay any judgment." 233 In declaring that the district court properly ordered specific performance, the Second Circuit cited Section 360 of the Restatement (Second) of Contracts for the proposition that "[e]ven if damages are adequate in other respects, they will be inadequate if they cannot be collected by judgment and execution." 234

In addressing the question of whether the injunctions violated the FSIA, the Second Circuit held that "because compliance with the injunctions would not deprive Argentina of control over any of its property, they do not operate as attachments of foreign property prohibited by the FSIA.” ${ }^{235}$ The court further held that the Injunctions at issue were not barred by Section 1609 of the FSIA, because the injunctions "do not attach, arrest, or execute upon any property." 236 The court reasoned that:

The Injunctions can be complied with without the court's [sic] ever exercising dominion over sovereign property. For example, Argentina can pay all amounts owed to its exchange bondholders provided it does the same for its defaulted bondholders. Or it can decide to make partial payments to its exchange bondholders as long as it pays a proportionate amount to holders of the defaulted bonds. Neither of these options would violate the Injunctions. The Injunctions do not require Argentina to pay any bondholder any amount of money; nor do they limit the other uses to which Argentina may put its fiscal reserves. In other words, the Injunctions do not transfer any dominion or control over

\footnotetext{
${ }^{231} \mathrm{Id}$. (alteration in original) (quoting the district court).

${ }^{232} I d$. at 250.

${ }^{233} \mathrm{Id}$. at 262.

234 NML Capital, Ltd. v. Republic of Argentina, 699 F.3d 246, 262 (2d Cir. 2012) (alteration in original).

${ }^{235} \mathrm{Id}$.

${ }^{236} I d$.
} 
sovereign property to the court. Accordingly, the district court's Injunctions do not violate § 1609. ${ }^{237}$

The court went on to hold that the FSIA does not preclude "the injunctive relief ordered by the district court, ${ }^{238}$ positing that:

Argentina voluntarily waived its immunity from the jurisdiction of the district court, and the FSIA imposes no limits on the equitable powers of a district court that has obtained jurisdiction over a foreign state, at least where the district court's use of its equitable powers does not conflict with the separate execution immunities created by $\S 1609 .^{239}$

The court concluded its FSIA analysis by declaring that "[a] federal court sitting as a court of equity having personal jurisdiction over a party has power to enjoin him from committing acts elsewhere.”240

On remand for clarification, the district court posited that "it is necessary that the process for making payments on the Exchange Bonds be covered by the Injunctions, and that the parties participating in that process be so covered," otherwise Argentina would simply ignore the injunctions. ${ }^{241}$ Upon review of the district court's amended injunctions, the Second Circuit addressed the argument that "the amended injunctions are improper or at a minimum violate comity where they extraterritorially enjoin payment systems that deliver funds to Exchange Bondholders."242 The court maintained its previous position, declaring that "a federal court sitting as a court of equity having personal jurisdiction over a party [here, Argentina] has power to enjoin him from committing acts elsewhere," ${ }^{243}$ and that "federal courts can enjoin conduct that has or is intended to have a substantial effect within the United States.”244

\section{B. The NML Case Was Wrongly Decided}

Before delving deeper into the specifics of the $N M L$ injunctions, it is important to begin with the general standard for issuing an injunction, as well

\footnotetext{
${ }^{237}$ Id. at 262-63.

${ }^{238} \mathrm{Id}$. at 263.

${ }^{239}$ Id. (citing Bano v. Union Carbide Corp., 361 F.3d 696, 716 (2d Cir.2004)).

${ }^{240} \mathrm{Id}$. at 262(quoting Bano, 361 at 716) (alteration in original) (internal quotation marks and citation omitted).

${ }^{241}$ NML Capital, Ltd. v. Republic of Argentina, No. 08 CIV. 6978, 2012 WL 5895786 at *4 (S.D.N.Y. Nov. 21, 2012) aff'd, 727 F.3d 230 (2d Cir. 2013).

242 NML Capital, Ltd. v. Republic of Argentina, 727 F.3d 230, 243 (2d Cir. 2013).

${ }^{243} \mathrm{Id}$. (alteration in original) (quoting another source) (internal quotation marks omitted).

${ }^{244} I d$. (quoting another source) (internal quotation marks omitted).
} 
as the reasoning behind the district court's decision to do so in $N M L{ }^{245}$ It is well-established that a "plaintiff seeking a permanent injunction must satisfy a four-factor test before a court may grant such relief." ${ }^{246}$ A plaintiff is required to demonstrate:

(1) that it has suffered an irreparable injury; (2) that remedies available at law, such as monetary damages, are inadequate to compensate for that injury; (3) that, considering the balance of hardships between the plaintiff and defendant, a remedy in equity is warranted; and (4) that the public interest would not be disserved by a permanent injunction. ${ }^{247}$

The Supreme Court has further declared that when crafting equitable remedies, courts "should pay particular regard for the public consequences in employing the extraordinary remedy of injunction."248 Additionally, where an injunction is sought against a sovereign defendant, a court must evaluate these four factors through the lens of the FSIA.

Although the FSIA embodies the sole exceptions by which a U.S. court may assert personal jurisdiction over a foreign state or execute against its property in satisfaction of a judgment, ${ }^{249}$ the statute itself is silent as to the effect, if any, the FSIA has on a court's powers to enjoin the conduct of a foreign state. ${ }^{250}$ Indeed, the word "injunction" does not appear in any section of the statute. ${ }^{251}$ What does appear in the statute is the declaration that where a foreign state is not entitled to immunity, "the foreign state shall be liable in the same manner and to the same extent as a private individual under like circumstances." ${ }^{252}$ In the legislative history pertaining to this particular section, Congress provides some guidance with respect to the availability of injunctive relief against a foreign state:

Consistent with this section, a court could, when circumstances were clearly appropriate, order an injunction or specific performance. But this is not determinative of the power of the court to enforce such an order. For example, a foreign diplomat or official could not be imprisoned for contempt because of his government's violation of an

\footnotetext{
245 Recall that the bonds at issue in NML are governed by New York law.

${ }^{246}$ Monsanto Co. v. Geertson Seed Farms, 561 U.S. 139, 130 S. Ct. 2743, 2756 (2010); see also eBay Inc. v. MercExchange, L.L.C., 547 U.S. 388, 391, (2006).

${ }^{247}$ Monsanto, 130 S. Ct. at 2756; see also eBay, 547 U.S. at 391.

${ }^{248}$ Winter v. Natural Res. Def. Council, Inc., 555 U.S. 7, 24 (2008).

${ }^{249}$ See generally 28 U.S.C. § 1602-10 (2014).

${ }^{250} \mathrm{Id}$.

${ }^{251} \mathrm{Id}$.

${ }^{252} I d$. at $\S 1606$.
} 
injunction. See 22 U.S.C. 252. Also a fine for violation of an injunction may be unenforceable if immunity exists under sections $1609-1610 .{ }^{253}$

Remember, Sections 1609 and 1610 contain rules that make attachment and execution unavailable with respect to the assets of foreign states, except in extremely limited circumstances. ${ }^{254}$ The plain language of those two sections, together with this language in the legislative history, creates no basis for believing that Congress intended injunctive relief to be available. When faced with the issue, this reading of the legislative history has been supported by five different circuits, one of which being the Second Circuit itself. ${ }^{255}$ This is because courts have recognized the risk for abuse that could follow a broader reading.

In Af-Cap, Inc. v. Republic of Congo, ${ }^{256}$ the Fifth Circuit recognized that under certain circumstances, the FSIA provides rights without remedies. In reversing a contempt order in which the district court imposed monetary sanctions against the Republic of Congo, the court pointed out that " $[t]$ he legislative history surrounding the FSIA specifically discusses contempt orders and states that they may be unenforceable if immunity exists." 257 After acknowledging that Section 1610 of the FSIA contains the only "available methods of attachment and execution against property of foreign states,"258 the court held that because that section does not authorize the use of monetary sanctions, the district court violated the FSIA when it included money sanctions in its order. ${ }^{259}$ The court concluded that "[u]nder the FSIA, a court's power to make an order does not always entail a power of enforcement by sanctions." "260 This conclusion has also been recognized by the Second Circuit. $^{261}$

In S \& S Mach. Co. v. Masinexportimport, the Second Circuit opined that "[t]he FSIA would become meaningless if courts could eviscerate its

${ }^{253}$ H.R. Rep. No. 94-1487, at 22 (1976), reprinted in 1976 U.S.C.C.A.N. 6604, 6621.

254 See U.S. 28 U.S.C. § 1609-10 (2014).

255 See, e.g., De Letelier v. Republic of Chile, 748 F.2d 790, 798-99 (2d Cir. 1984); Af-Cap, Inc. v. Republic of Congo, 462 F.3d 417, 429 (5th Cir. 2006); Autotech Technologies LP v. Integral Research \& Dev. Corp., 499 F.3d 737, 749-50 (7th Cir. 2007); Peterson v. Islamic Republic Of Iran, 627 F.3d 1117, 1128 (9th Cir. 2010); FG Hemisphere Associates, LLC v. Democratic Republic of Congo, 637 F.3d 373, 377 (D.C. Cir. 2011).

${ }^{256}$ Af-Cap, Inc. v. Republic of Congo, 462 F.3d 417 (5th Cir. 2006).

${ }^{257} \mathrm{Id}$. at 428 (alteration in original) (quoting another source) (internal quotation marks omitted).

${ }^{258} \mathrm{Id}$.

${ }^{259}$ Id. at 428-29.

${ }^{260} \mathrm{Id}$. at 429.

261 De Letelier, 748 F.2d at 798-99 (holding that Congress created a right without a remedy when it "restricted immunity from execution against agencies and instrumentalities [of a foreign state], but was more cautious when lifting immunity from execution against property owned by the State itself") (alteration in original). 
protections merely by denominating their restraints as injunctions against the negotiation or use of property rather than as attachments of that property."262 The court further held that courts "may not grant, by injunction, relief which they may not provide by attachment." ${ }^{263}$ Thus, where an injunction would be functionally equivalent to an attachment, arrest, or execution, it is a violation of the FSIA. ${ }^{264}$

Recall, in the legislative history of the FSIA, Congress expressly acknowledged that "a court could, when circumstances were clearly appropriate, order an injunction or specific performance. But this is not determinative of the power of the court to enforce such an order."265 Moreover, the Second Circuit itself has held that "[t]he FSIA would become meaningless if courts could eviscerate its protections merely by denominating their restraints as injunctions against the negotiation or use of property rather than as attachments of that property."266 Thus, applying these principles to the considerations outlined in Bano v. Carbide Corp, ${ }^{267}$ it is difficult to understand why the Second Circuit upheld the district court's injunctions in the NML case. The Second Circuit cannot deny that it ultimately cannot "secure compliance" from Argentina, nor can it dispute that the resulting injunctions have already created "discord and conflict" with the authorities of Argentina. ${ }^{268}$

It is worth remembering that the Supreme Court has held that courts should interpret statutes in light of the presumption that "Congress ordinarily intends its statutes to have domestic, not extraterritorial, application." 269 The Supreme Court reaffirmed this presumption in Kiobel v. Royal Dutch Petroleum Co., where it held that "[w]hen a statute gives no clear indication

262 S \& S Machinery Co. v. Masinexportimport, 706 F.2d 411, 418 (1983).

${ }^{263} \mathrm{Id}$.

264 See Id.; see also Janvey v. Libyan Inv. Auth., No. 12-10240, 2012 WL 2136603, at *236, (5th Cir. June 13, 2012) (holding that preliminary injunction effectively freezing funds "would serve the same purpose as an attachment," and thus was a violation of the FSIA); Phoenix Consulting Inc. v. Republic of Angola, No. 98-7021, 1998 WL 794854, at*1 (D.C. Cir. Oct. 20, 1998) (“Furthermore, to the extent the preliminary injunction sought to prevent the Republic of Angola from transferring money, it constituted in effect a prejudgment attachment in violation of the Foreign Sovereign Immunities Act ....”).

265 See H.R. Rep. No. 94-1487, at 22 (1976), reprinted in 1976 U.S.C.C.A.N. 6604, 6621.

${ }^{266}$ S \& S Machinery, 706 F.2d at 418; see also Janvey v. Libyan Inv. Auth., No. 12-10240, 2012 WL 2136603, at *236, (5th Cir. June 13, 2012) (holding that preliminary injunction effectively freezing funds "would serve the same purpose as an attachment," and thus was a violation of the FSIA); Phoenix Consulting Inc. v. Republic of Angola, No. 98-7021, 1998 WL 794854, at *1 (D.C. Cir. Oct. 20, 1998) ("Furthermore, to the extent the preliminary injunction sought to prevent the Republic of Angola from transferring money, it constituted in effect a prejudgment attachment in violation of the Foreign Sovereign Immunities Act. . . .").

267 Bano v. Union Carbide Corp., 361 F.3d 696 (2d Cir. 2004) [hereinafter Bano]; See infra p. 198. 268 NML Capital, Ltd. v. Republic of Argentina, 727 F.3d 230, 238 (2d Cir. 2013) (observing that Argentina has repeatedly expressed its intent to disobey the injunctions).

${ }^{269}$ Small v. United States, 544 U.S. 385, 388-89 (2005). 
of an extraterritorial application, it has none.”270 The Court explained that "[t]his presumption serves to protect against unintended clashes between our laws and those of other nations which could result in international discord." ${ }^{271}$ The Court concluded that:

For us to run interference in... a delicate field of international relations there must be present the affirmative intention of the Congress clearly expressed. It alone has the facilities necessary to make fairly such an important policy decision where the possibilities of international discord are so evident and retaliative action so certain. The presumption against extraterritorial application helps ensure that the Judiciary does not erroneously adopt an interpretation of U.S. law that carries foreign policy consequences not clearly intended by the political branches. ${ }^{272}$

Thus, although Congress acknowledged that "a court could, when circumstances were clearly appropriate, order an injunction or specific performance,"273 it is highly unlikely that Congress was contemplating the type of injunction issued by the district court in NML. Indeed, it is difficult to imagine that Congress intended a U.S. court to have the power to enjoin a foreign state "from altering or amending the processes or specific transfer mechanisms by which it makes payments due" ${ }^{274}$ to its bondholders.

It is even more unlikely that Congress envisioned the utilization of Rule $65^{275}$ to coerce a foreign state's compliance with an injunction, thereby providing an alternative to the intentionally narrow enforcement provisions of the FSIA, simply because, in the court's opinion, money damages would "be inadequate if they cannot be collected by judgment and execution."276 This leaves but one conclusion. By issuing a permanent injunction enjoining Argentina from altering the processes and intermediaries it uses to service its debt obligations to holders of the Exchange Bonds and ordering the distribution of notice of the injunctions to "all parties involved, directly or indirectly, in advising upon, preparing, processing, or facilitating any

${ }^{270}$ Kiobel v. Royal Dutch Petroleum Co., 133 S. Ct. 1659, 1664 (2013) (quoting Morrison v. National Australia Bank Ltd., 130 S. Ct. 2869, 2878) (internal quotation marks omitted).

${ }^{271} \mathrm{Id}$. (alteration in original) (quoting another source).

272 Id. (quoting another source) (internal quotation marks omitted).

${ }^{273}$ H.R. Rep. No. 94-1487, at 22 (1976), reprinted in 1976 U.S.C.C.A.N. 6604, 6621.

274 NML Capital, Ltd. v. Republic of Argentina, 699 F.3d 246, 254 (2d Cir. 2012).

${ }^{275}$ Fed. R. Civ. P. 65(d) empowers a court to enjoin the conduct of the parties, the parties' officers, agents, servants, employees, attorneys, and any "other persons who are in active concert or participation with anyone described in Rule 65(d)(2)(A) or (B)," to the extent that such conduct violates an injunction of which the third party has actual notice.

${ }^{276}$ NML Capital, Ltd. v. Republic of Argentina, 699 F.3d 246, 262 (2d Cir. 2012). 
payment on the Exchange Bonds,"277 the district court was attempting to circumvent the enforcement provisions of the FSIA by leaving Argentina with no choice but to pay its holdout creditors.

If this sounds familiar, it should, because it is precisely the same unenviable situation in which Peru found itself in Elliott Associates following the Brussels Court of Appeals' ex parte injunction blocking its interest payment to holders of its restructured debt. ${ }^{278}$ Thus, while the Second Circuit has proclaimed that the injunctions do not run afoul of the FSIA because "[t]he Injunctions do not require Argentina to pay any bondholder any amount of money; nor do they limit the other uses to which Argentina may put its fiscal reserves," ${ }^{279}$ the reality is that the injunctions have presented Argentina with a Hobson's choice: 1) comply with the district court's injunctions, which would mean paying the $N M L$ plaintiffs approximately $\$ 1.33$ billion; ${ }^{280}$ or 2 ) default on its payment obligations to creditors holding over $\$ 70$ billion in Exchange Bonds. ${ }^{281}$

Thus, the Second Circuit was misguided in opining that the FSIA has not been violated because the injunctions do not "transfer any dominion or control over sovereign property to the court," 282 and that "the injunctions allow Argentina to pay its FAA debts with whatever resources it likes." ${ }^{283}$ If not an attachment, the injunctions imposed upon Argentina were at least an arrest of its property. In evaluating the legality of the injunctions, the Second Circuit defined "arrest" as "[a] seizure or forcible restraint." ${ }^{284}$ What seems to have evaded the court is that while the district court may not literally have dominion or control over Argentina's sovereign property (i.e. the funds Argentina has earmarked for payment to holders of its Exchange Bonds), neither does Argentina. Because no prudent financial intermediary would be willing to risk facing liability for aiding Argentina in violation of the injunctions, Argentina has been deprived of its power to decide how and to whom it will make payments, thus resulting in the functional equivalent of an arrest of its property, if not an attachment.

In reaching its conclusion, the $N M L$ court cited Bano $^{285}$ as precedent. This is extremely surprising since Bano, ${ }^{286}$ when viewed in its proper context, supports a result contrary to the Second Circuit's analysis in NML. Indeed, in

\footnotetext{
${ }^{277} \mathrm{Id}$. at 255.

${ }^{278}$ See discussion supra Part I.B.1.

${ }^{279}$ NML Capital, Ltd. v. Republic of Argentina, 699 F.3d 246, 263 (2d Cir. 2012).

${ }^{280} \mathrm{Id}$. at 251.

${ }^{281}$ Id. at 251-53.

282 Id. at 263.

283 NML Capital, Ltd. v. Republic of Argentina, 727 F.3d 230, 240-41 (2d Cir. 2013).

${ }^{284}$ NML Capital, Ltd. v. Republic of Argentina, 699 F.3d 246, 262 (2d Cir. 2012) (quoting BLACK’s LAW DiCTIONARY 124 n.13 (9th ed. 2009).

${ }^{285}$ Bano v. Union Carbide Corp., 361 F.3d 696 (2d Cir. 2004).

${ }^{286} I d$.
} 
Bano, the court began by citing the Restatement (Second) of Torts for the proposition that " $[\mathrm{t}]$ he practicability of drafting and enforcing an order or judgment for an injunction is one of the factors to be considered in determining the appropriateness of injunction against tort." 287 The court continued, holding that a

federal court sitting as a court of equity having personal jurisdiction over a party has power to enjoin him from committing acts elsewhere. But this power should be exercised with great reluctance when it will be difficult to secure compliance with any resulting decree or when the exercise of such power is fraught with possibilities of discord and conflict with the authorities of another country. ${ }^{288}$

The court concluded by declaring that "[i]f drafting and enforcing are found to be impracticable, the injunction should not be granted." 289

In Rubin v. Islamic Republic of Iran, the Seventh Circuit was asked to determine whether a plaintiff can request that a court-having properly asserted personal jurisdiction over a foreign state—can issue a general-asset discovery order for all of the foreign state's property located in the U.S. ${ }^{290}$ In holding that a "court cannot compel a foreign state to submit to general discovery about all its assets in the United States," 291 the court pointed out that "[a]lthough [a foreign state] may be found liable in the same manner as any other private defendant, the options for executing a judgment remain limited." 292 The court concluded:

That is the point of $\S 1609$. It is true that $\S \S 1604$ and 1609 provide different kinds of immunity to foreign sovereigns, but there is no reason to read $\S 1609$ to allow for more intrusive discovery than its $\S 1604$ counterpart. To the contrary, as we observed in Autotech, the exceptions to $\S$ 1609 attachment immunity are drawn more narrowly than the exceptions to $\S 1604$ jurisdictional immunity. ${ }^{293}$

However, in $N M L$, it would appear that once the district court was satisfied that the plaintiffs overcame the first hurdle presented by the FSIAArgentina's jurisdictional immunity—the court simply allowed the plaintiffs

\footnotetext{
${ }^{287}$ Id. at 716.

${ }^{288} I d$. (alteration in original).

${ }^{289}$ Id. (internal quotations omitted).

${ }^{290} 637$ F.3d 783, 785 (7th Cir. 2011).

${ }^{291} \mathrm{Id}$.

${ }^{292} \mathrm{Id}$. at 797.

${ }^{293}$ Id. (alteration in original).
} 
to sidestep the second hurdle. This conclusion is bolstered by the Second Circuit's brisk treatment of Argentina's argument that the injunctions violated its attachment immunities. The court was content with proclaiming that the injunctions "affect Argentina's property only incidentally to the extent that the order prohibits Argentina from transferring money to some bondholders and not others," 294 invoking the rule of law that "[a] federal court sitting as a court of equity having personal jurisdiction over a party has power to enjoin him from committing acts elsewhere," ${ }^{295}$ and moving on. But as the Seventh Circuit pointed out in Rubin, "[t]he critical error in this argument is that it mixes the scope of liability with the scope of execution."296

Perhaps the Second Circuit should have given more consideration to its own precedent. Specifically, that courts "may not grant, by injunction, relief which they may not provide by attachment." ${ }^{297}$ Moreover, the Second Circuit has previously recognized that "[ $\mathrm{t}]$ he FSIA would become meaningless if courts could eviscerate its protections merely by denominating their restraints as injunctions against the negotiation or use of property rather than as attachments of that property." 298

The best possible explanation for the Second Circuit's decision in NML is that the court was motivated by a desire to hold foreign states accountable for their contractual obligations. Indeed, a cursory overview of the Second Circuit's sovereign default jurisprudence reveals several manifestations of this desire. Since the mid-1980s, the Second Circuit has eliminated several major defenses employed by foreign states to evade litigation, certified the viability of holdout strategies, and arguably facilitated the proliferation of vulture fund litigation. ${ }^{299}$ Moreover, at times there have also been very distinct "freedom of contract" themes underlying the courts decisions, if not driving them. For example, recall that in Allied Bank, the Second Circuit declared:

The United States has an interest in maintaining New York's status as one of the foremost commercial centers in the world. Further, New York is the international clearing center for United States dollars. In addition to other international activities, United States banks lend billions of dollars to foreign debtors each year. The United States has an interest

\footnotetext{
${ }^{294}$ NML Capital, Ltd. v. Republic of Argentina, 699 F.3d 246, 262 (2d Cir. 2012) (alteration in original).

${ }^{295} \mathrm{Id}$. at 263(alteration in original) (internal quotations omitted) (citing another source).

${ }^{296}$ Rubin v. Islamic Republic of Iran, 637 F.3d 783, 797 (7th Cir. 2011).

${ }^{297}$ S \& S Machinery Co. v. Masinexportimport, 706 F.2d 411, 418 (1983).

${ }^{298} \mathrm{Id}$.

299 See e.g., Allied Bank Int'l v. Banco Credito Agricola de Cartago, 757 F.2d 516 (2d Cir. 1985) (eliminating the Act of State doctrine and Comity as a defense for foreign states); Elliott Associates, L.P. v. Banco de la Nacion, 194 F.3d 363 (2d Cir. 1999) (eliminating the Champerty defense).
} 
in ensuring that creditors entitled to payment in the United States in United States dollars under contracts subject to the jurisdiction of United States courts may assume that, except under the most extraordinary circumstances, their rights will be determined in accordance with recognized principles of contract law. ${ }^{300}$

But Congress's intent in enacting the FSIA was not to make it as easy as possible for creditors to satisfy judgments against sovereign debtors. Rather, the FSIA was intended to codify the restrictive theory of sovereign immunity. This is evident from the narrow set of exceptions under which a judgment creditor can seek to attach the property of a foreign state in satisfaction of its judgment. Absent the availability of one of these exceptions, the property of a foreign state enjoys immunity from execution. As the Seventh Circuit observed in Autotech Technologies LP v. Integral Research \& Dev. Corp., "[t]he FSIA did not purport to authorize execution against a foreign sovereign's property, or that of its instrumentality, wherever that property is located around the world. We would need some hint from Congress before we felt justified in adopting such a breathtaking assertion of extraterritorial jurisdiction." ${ }^{301}$ For these reasons, it is far more common for a judgment creditor to find itself unable to satisfy its judgment for lack of attachable property than it is for a foreign state to promptly cut a check to a judgment creditor. ${ }^{302}$

Arguably, the Second Circuit's observations regarding the propriety of equitable relief due to the absence of an effective legal remedy by which Argentina's creditors can satisfy their judgments were not made through the lens of the FSIA. In the context of sovereign debt litigation, where the sovereign debtor refuses to pay its debt and has no attachable assets in the U.S., the judgment creditor will technically never have an adequate legal remedy. ${ }^{303}$ If courts were allowed to grant equitable relief-such as the injunctions imposed on Argentina in NML-any time a judgment creditor could prove that its sovereign debtor had no attachable assets in the U.S., Sections 1609 and 1610 of the FSIA would be completely undermined.

\footnotetext{
${ }^{300}$ Allied Bank, 757 F.2d at 521-22.

301499 F.3d 737, 750 ( $7^{\text {th }}$ Cir. 2007).

${ }^{302}$ See Fisch \& Gentile, supra note 28, at 1086 ("Defaulting sovereigns, however, rarely leave assets in jurisdictions in which attachment is possible.”); see also Foster, supra note 170, at 665, 668 ("In most cases, however, the response will fall somewhere in between. Oftentimes, officials will express a desire to pay the debt, but the creditor is left waiting in vain for payment to be made.”); Schumacher et al., supra note 27, at 12 ("[T] he share of lawsuits with attempted asset seizures has increased from below $20 \%$ in the early 1990 s to over $50 \%$ in recent years.”).

303 Of course, a judgment creditor could still seek to attach property abroad, but if no assets were available, the judgment creditor would have no further recourse.
} 
Indeed, in the legislative history accompanying the FSIA, Congress acknowledged that "the traditional view in the United States concerning execution has been that the property of foreign states is absolutely immune from execution," 304 but that "[s]ections 1610(a) and (b) are intended to modify this rule by partially lowering the barrier of immunity from execution ....”305 Thus, it was not Congress' intent that a court would be constrained by the FSIA only to the extent that it provided an adequate mechanism by which a judgment creditor could satisfy its judgment. Rather, it is clear from the foregoing that Congress intentionally limited a judgment creditors enforcement avenues to the specifically designated exceptions contained in Section 1610. If none of the exceptions apply, the general rule of absolute immunity is reinstated, and the judgment creditor is precluded from further interference with the foreign state's property.

Returning to the $N M L$ case, recall that on May 10, 2006, Judge Thomas Griesa awarded NML Capital summary judgment on its underlying claim and approximately $\$ 248$ million in damages. ${ }^{306}$ From then on, NML Capital has actively pursued attachment of Argentina's assets worldwide. ${ }^{307}$ Thus, NML Capital had in fact been availing itself of a legal remedy for quite some time. Simply because its enforcement campaign was unsuccessful does not change the fact that the opportunity to attach assets was — and remains — a possibility. It is not the Second Circuit's place to enlarge the scope of the FSIA. Congress enacted the FSIA with careful consideration, adopting narrow exceptions to the general rule of absolute sovereign immunity, and while cognizant of the inherently volatile nature of sovereigns. ${ }^{308}$

\section{RECOMMENDATIONS}

Under Section 1609 of the FSIA, a foreign state enjoys a strong and unequivocal presumption of immunity from attachment, arrest, and execution, with respect to its property located in the United States. ${ }^{309}$ Only under extremely limited circumstances can a foreign state lose this

\footnotetext{
${ }^{304}$ H.R. Rep. No. 94-1487, at 27 (1976) (alteration in original).

${ }^{305}$ Id. (alteration in original).

${ }^{306}$ NML Capital, Ltd. v. Republic of Argentina, 2006 WL 1294853 (S.D.N.Y. May 10, 2006).

307 See e.g. Proctor, supra note 182, at 736 (detailing NML Capital's attempts to enforce its judgment in the U.K.); James Kraska, The "Ara Libertad" (Argentina v. Ghana), 107 AM. J. INT'L L. 404 (2013) (describing NML Capital's attempt to execute on an Argentine ship in order to satisfy its judgment); Gilles Cuniberti, French Supreme Court Upholds Argentina's Immunity Despite Waiver, (April 2, 2013), http://conflictoflaws.net/2013/french-supreme-court-upholds-argentinasimmunity-despite-waiver/ ("In the summer 2009, NML Capital initiated enforcement proceedings in Europe.”).

${ }^{308}$ H.R. Rep. No. 94-1487, at 27 (1976) (acknowledging that attachment of a foreign state's property can negatively impact foreign relations).

30928 U.S.C. § 1609 (2014).
} 
immunity. ${ }^{310}$ In $N M L$, the district court, apparently dissatisfied with the present scope of the FSIA's remedial provisions, granted injunctive relief to Argentina's creditors. ${ }^{311}$ The court justified its decision on the grounds that Argentina had violated a pari passu clause contained in the bonds after it defaulted on bonds held by the plaintiffs-a cohort of holdout creditors-yet continued to make payments to Exchange bondholders. ${ }^{312}$

The court reasoned that an equitable remedy was warranted because Argentina was adamant in its refusal to pay these plaintiffs, it regularly serviced its obligations to Exchange bondholders, and it had no attachable assets in the United States. Thus, the district court enjoined Argentina from making any further payments to Exchange bondholders without simultaneously making ratable payments to the plaintiffs. ${ }^{313}$ The district court further enjoined Argentina from altering or amending the processes it uses to service its obligations to Exchange bondholders. ${ }^{314}$ The implications of this were twofold. First, it allowed the court to identify the financial intermediaries Argentina used to service its debt and to be certain that these entities would not change. Second, it gave the court leverage to coerce Argentina's compliance with the injunctions by operation of Rule 65.

The court ordered the distribution of notice of the injunctions to "all parties involved, directly or indirectly, in advising upon, preparing, processing, or facilitating any payment on the Exchange Bonds.”315 Pursuant to Rule 65, any party receiving such notice would be exposed to liability in the event that it assisted Argentina in violating the injunctions. Thus, while Argentina is purportedly free to do as it wishes with the funds it has earmarked for paying its obligations to the Exchange bondholders, the reality of the situation is that its financial intermediaries are no longer willing to make payments to the Exchange bondholders on behalf of Argentina for fear of exposing themselves to liability.

In light of the Supreme Court's denial of Argentina's petition for writ of certiorari, ${ }^{316}$ Congress should abrogate the Second Circuit's opinion by amending the FSIA. The district court granted a remedy which was not authorized under the FSIA. The FSIA contains a distinct dichotomy between a foreign state's jurisdictional immunity and its immunity from attachment, arrest, and execution, with respect to property it holds in the United States. It is clear from the plain language of the statute that the exceptions to the latter are far narrower than those pertaining to the former. Accordingly, a

310 See 28 U.S.C. $§ 1610$ (2014).

311 NML Capital, Ltd. v. Republic of Argentina, No. 08 CIV. 6978, 2012 WL 5895786 at *4 (S.D.N.Y. Nov. 21, 2012) aff'd, 727 F.3d 230 (2d Cir. 2013).

312 Id.

${ }^{313} \mathrm{Id}$. at $* 3-4$.

${ }^{314}$ NML Capital, Ltd. v. Republic of Argentina, 699 F.3d 246, 254 (2d Cir. 2012).

${ }^{315} \mathrm{Id}$. at 255

${ }^{316}$ See supra note 17. 
foreign state may not be deemed to have lost its immunity from attachment, arrest, or execution simply by virtue of having lost its immunity from jurisdiction. Thus, although the FSIA provides that a foreign state which has lost its immunity from jurisdiction "shall be liable in the same manner and to the same extent as a private individual under like circumstances," 317 the remedies available to prevailing plaintiffs remain limited by the provisions of Sections 1609 and 1610.

However, the NML court ignored this distinction and declared that "a federal court sitting as a court of equity having personal jurisdiction over a party has power to enjoin him from committing acts elsewhere," ${ }^{318}$ and that "federal courts can enjoin conduct that has or is intended to have a substantial effect within the United States." ${ }^{319}$ But again, "[t]he critical error in this argument is that it mixes the scope of liability with the scope of execution." 320 Accordingly, the Second Circuit's decision must be abrogated. The Supreme Court has previously recognized that "[t]he presumption against extraterritorial application helps ensure that the Judiciary does not erroneously adopt an interpretation of U.S. law that carries foreign policy consequences not clearly intended by the political branches." ${ }^{321}$ Therefore, it is for Congress to amend the FSIA, not the Second Circuit. If Congress had intended for this type of injunctive relief to be available, it would have been included in Section 1609 or 1610. The fact that Congress briefly, and skeptically, referenced injunctions in the legislative history accompanying the FSIA, yet omitted any reference to "injunctions" or "injunctive relief" from the final iteration of the FSIA, indicates that Congress did not intend for injunctive relief to supplement the narrow exceptions to attachment and execution it carefully drafted in Section 1610.

Although the NML injunctions have been framed as a remedy to Argentina's breach of the pari passu clause, rather than a pure enforcement of the clause itself, ${ }^{322}$ the practical implications remain the same. Recall that in Elliott Associates, the Brussels court held that the pari passu clause at issue entitled Elliott to a pro rata share of any payments Peru made to its creditors. ${ }^{323}$ Much has been written on the aftermath of the decision in Elliott Associates, as well as the potential dangers that await if something is not done

\footnotetext{
31728 U.S.C. § 1606 (2014).

318 NML Capital, Ltd. v. Republic of Argentina, 727 F.3d 230, 243 (2d Cir. 2013) (quoting another source) (internal quotation marks omitted).

${ }^{319} \mathrm{Id}$. (quoting another source) (internal quotation marks omitted).

${ }^{320}$ Rubin v. Islamic Republic of Iran, 637 F.3d 783, 797 (7th Cir. 2011).

${ }^{321} \mathrm{Id}$. (alteration in original) (quoting another source) (internal quotation marks omitted).

322 Zamour, supra note 1 , at 64 .

${ }^{323}$ See Buchheit \& Pam, supra note 122, at 879.
} 
to quell the burgeoning vulture fund industry. ${ }^{324}$ This call to arms against vulture funds is largely anchored by the fear that holdout creditors have the ability to impede sovereign debt restructurings, which can not only lead to a longer, more difficult road to recovery for sovereign debtors, but can also have detrimental effects on international markets and sovereign relations. ${ }^{325}$ Moreover, in addition to incentivizing creditors to emulate prevailing strategies, holdout creditor victories in cases such as Elliott Associates and $N M L$ encourage creditors to employ innovative and novel approaches to satisfying judgment awards. ${ }^{326}$ However, vulture funds are not without their supporters. Some commentators argue that vulture funds serve the important purposes of promoting market efficiency, accountability, and fairness. ${ }^{327}$

Interestingly enough, regardless of which side of the fence they are on, several commentators point out that the tension between holdout creditors and recalcitrant sovereign debtors is but one problem amongst many. ${ }^{328}$ One thing is for certain, when it comes to issues that have the potential to significantly impact sovereign relations, decision-makers should tread lightly. This principle did not escape Congress in its initial drafting of the FSIA, nor did it escape Belgium's legislature following the Elliott Associates decision. ${ }^{329}$ On November 19, 2004, Belgium passed legislation aimed at avoiding "disruptive actions by creditors by attaching cash accounts held with Belgium clearing systems or obtaining injunctions such as the ones obtained by Elliot[t] . ...”330 The U.K. has also taken a hard line with vulture funds via its Debt Relief (Developing Countries) Act, which closed the doors of U.K. courts to vulture funds seeking to bring actions against "Heavily Indebted Poor Countries.” ${ }^{331}$ Moreover, the U.K.’s SIA expressly prohibits injunctions from being issued against foreign states. ${ }^{332}$

324 See generally Olivares-Caminal, supra note 90; Blackman \& Mukhi, supra note 70, at 47; Vulture Funds and Poor Country Debt: Recent Developments and Policy Responses, Jubilee USA Network (April 2008), http://www.jubileeusa.org/fileadmin/user_upload/Resources/ Policy_Archive/408briefnotevulturefunds.pdf.

${ }^{325}$ See Lippert, supra note 30, at 27-32; see also Fisch \& Gentile, supra note 28, at 1088-89.

${ }^{326}$ See generally Schumacher et al., supra note 27, at 2.

${ }^{327}$ See Jonathan Goren, Note, State-to-State Debts: Sovereign Immunity and the "Vulture" Hunt, 41 GEO. WASH. INT'L L. REV. 681, 689-694 (2010); Fisch \& Gentile, supra note 27, at 1097-1101.

328 See e.g., Charles Seavey, Note, The Anomalous Lack of an International Bankruptcy Court, 24 Berkeley J. INT'L L. 499 (2006); David P. Stewart, The UN Convention on Jurisdictional Immunities of States and Their Property, 99 AM. J. INT'L L. 194 (2005) (observing the lack of uniform treatment of sovereign immunity in the global community); Baumgartner, supra note 169, at 965 (explaining the lack of consistent treatment of U.S. judgments abroad).

329 See Elizabeth Broomfield, Note, Subduing the Vultures: Assessing Government Caps on Recovery in Sovereign Debt Litigation, 2010 Colum. Bus. L. REv. 473, 503-04 (2010) (noting that Belgium was the first country to pass anti-vulture fund legislation).

330 Rodrigo Olivares-Caminal, Understanding the Pari Passu Clause in Sovereign Debt Instruments: A Complex Quest, 43 INT'L LAW. 1217, 1234 (2009) (alteration in original).

${ }^{331}$ Olivares-Caminal, supra note 90, at 53.

332 State Immunity Act, 1978, c. 33(2)(a) (Eng.). 
Just as Congress looked to the norms of the international community in codifying the restrictive theory of sovereign immunity, it would be welladvised to again survey the international landscape in determining how to respond to the NML decision. If the Supreme Court declines Argentina's petition for certiorari, Congress should amend the FSIA to prohibit courts from using injunctions and Rule 65 to circumvent Sections 1609 and 1610.

Considering that the "majority of bonds issued by emerging market sovereigns are governed either by New York state law or English law," ${ }^{333}$ if Congress does in fact share the Second Circuit's sentiments with respect to preserving the prominent status of the New York bond market, it would be wise to, at a minimum, keep the United States' treatment of sovereign debtors in line with that of the U.K. Accordingly, Congress should amend Sections 1609 and 1610 of the FSIA to expressly prohibit permanent injunctions from being imposed upon foreign states. This is necessary to preclude courts from using Rule 65, in conjunction with a permanent injunction, to affect the functional equivalent of an arrest, attachment, or execution of a foreign state's property. It is no excuse that such a result in the indirect effect of a court's order, whereby the court directly strikes fear into third parties whom, under threat of liability, are no longer willing to assist a foreign state in exercising its right as a sovereign nation to ignore an order of specific performance from a court sitting in a foreign country.

\section{CONCLUSION}

There are several macro issues that must be resolved in order to level the playing field in sovereign debt litigation. This does not simply mean taking the wind out of the sails of vulture funds or strengthening defenses for foreign states. Just as it is unfair for a vulture fund to prey on weak sovereign debtors, it is equally unfair for a sovereign debtor that has the means to pay its creditors to simply elect to default on its external debt for no reason other than to leverage better terms on its debt instruments. If nothing else, the $N M L$ case has again placed the topic of sovereign default in the international spotlight, which, with any luck, will be the impetus for a revitalization of previous efforts to institute substantive reform, such as the institution of a sovereign bankruptcy court or more uniform recognition of foreign judgments abroad.

333 Alinna Arora, Rodrigo Olivares Caminal, Rethinking the Sovereign Debt Restructuring Approach, 9 L. \& Bus. REV. AM. 629, 637 (2003). 